\title{
Review \\ Glial Cell Dysfunction in C9orf72-Related Amyotrophic Lateral Sclerosis and Frontotemporal Dementia
}

\author{
Mehdi Ghasemi *(D), Kiandokht Keyhanian and Catherine Douthwright \\ Department of Neurology, University of Massachusetts Medical School, Worcester, MA 01655, USA; \\ kiandokht.keyhanian@umassmemorial.org (K.K.); catherine.douthwright@umassmed.edu (C.D.) \\ * Correspondence: mehdi.ghasemi@umassmemorial.org; Tel.: +1-774-441-7726; Fax: +1-508-856-4485
}

Citation: Ghasemi, M.; Keyhanian, K.; Douthwright, C. Glial Cell Dysfunction in C9orf72-Related Amyotrophic Lateral Sclerosis and Frontotemporal Dementia. Cells 2021, 10, 249. https://doi.org/10.3390/ cells10020249

Academic Editors: Kyoungho Suk, Makoto Tsuda and Hoon Ryu Received: 30 December 2020

Accepted: 25 January 2021

Published: 28 January 2021

Publisher's Note: MDPI stays neutral with regard to jurisdictional claims in published maps and institutional affiliations.

Copyright: (c) 2021 by the authors. Licensee MDPI, Basel, Switzerland. This article is an open access article distributed under the terms and conditions of the Creative Commons Attribution (CC BY) license (https:// creativecommons.org/licenses/by/ $4.0 /)$.

\begin{abstract}
Since the discovery of the chromosome 9 open reading frame 72 (C9orf72) repeat expansion mutation in 2011 as the most common genetic abnormality in amyotrophic lateral sclerosis (ALS, also known as Lou Gehrig's disease) and frontotemporal dementia (FTD), progress in understanding the signaling pathways related to this mutation can only be described as intriguing. Two major theories have been suggested-(i) loss of function or haploinsufficiency and (ii) toxic gain of function from either C9orf72 repeat RNA or dipeptide repeat proteins (DPRs) generated from repeat-associated non-ATG (RAN) translation. Each theory has provided various signaling pathways that potentially participate in the disease progression. Dysregulation of the immune system, particularly glial cell dysfunction (mainly microglia and astrocytes), is demonstrated to play a pivotal role in both loss and gain of function theories of C9orf72 pathogenesis. In this review, we discuss the pathogenic roles of glial cells in C9orf72 ALS/FTD as evidenced by pre-clinical and clinical studies showing the presence of gliosis in C9orf72 ALS/FTD, pathologic hallmarks in glial cells, including TAR DNA-binding protein 43 (TDP-43) and p62 aggregates, and toxicity of C9orf72 glial cells. A better understanding of these pathways can provide new insights into the development of therapies targeting glial cell abnormalities in C9orf72 ALS/FTD.
\end{abstract}

Keywords: C9orf72 gene; C9orf72 repeat expansion mutation; amyotrophic lateral sclerosis (ALS); frontotemporal dementia (FTD); astrocytes; microglia; glial cells

\section{Introduction}

Amyotrophic lateral sclerosis (ALS, also known as Lou Gehrig's disease) and frontotemporal dementia (FTD) are two devastating neurodegenerative diseases with a high burden on society. It is currently believed that ALS and FTD are parts of a disease spectrum that share clinical, genetic, and pathological findings. Clinically, 30-50\% of ALS patients have cognitive deficits, and $\sim 15 \%$ of patients with FTD exhibit symptoms/signs of ALS [1,2]. Histopathological studies have also shown that $>97 \%$ of ALS and $\sim 50 \%$ of FTD patients aggregate inclusions of the TAR DNA-binding protein 43 (TDP-43) in both affected neurons and glial cells [3-7]. In 2011, a trio of teams [8-10] discovered a GGGGCC $\left(\mathrm{G}_{4} \mathrm{C}_{2}\right)$ nucleotide repeat expansion mutation in the first intron of the chromosome 9 open reading frame 72 (C9orf72) gene as the most frequent genetic cause in up to 35-45\% of familial ALS, 5-20\% of sporadic ALS, 15-25\% of familial FTD, and 6-7\% of sporadic FTD patients [11]. Although the number of hexanucleotide repeats varies considerably among these patients, overall, repeat numbers of $<30$ are considered to be non-pathogenic [12] The relationship between repeat expansion size and phenotype is still equivocal, which could be due to somatic variability in expansion size [2]. C9orf72 ALS patients have a mean onset age of 57 years old and a median survival rate of 30-37 months [13]. Although more frequent bulbar onset has been reported in C9orf72 ALS patients compared to ALS patients without a C9orf72 repeat expansion mutation [14-16], this is still debatable, because a recent multi-center prospective natural history study on C9orf72 ALS cases reported a 
higher rate of limb (54\%) than bulbar (39\%) onset [13]. What is undebatable, however, is that the prevalence of FTD is significantly higher in C9orf72 ALS cases, accompanied by higher rates of disease progression and prominent cognitive/behavioral changes $[14,17]$ (Figure 1). Co-morbid dementia is present in 50\% of C9orf72 ALS patients [14]. C9orf72 FTD patients have also more common psychotic features and irrational behavior compared to non-C9orf72 FTD cases [18,19].

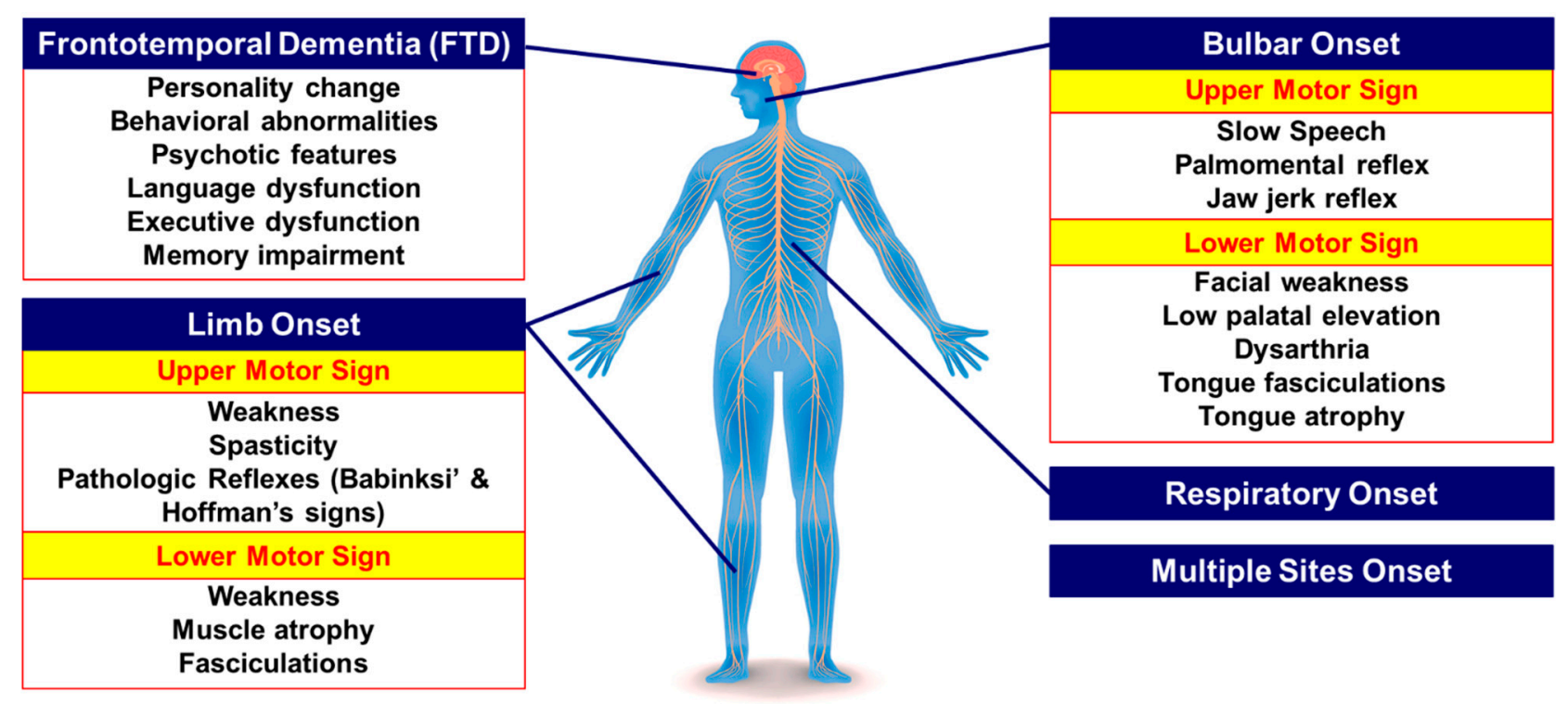

Figure 1. Clinical findings at onset in the chromosome 9 open reading frame 72 (C9orf72)-associated amyotrophic lateral sclerosis (ALS) / frontotemporal dementia (FTD).

Although much more research is needed to understand the normal function of $C 9$ orf 72 in humans, the discovery of C9orf72 repeat expansion mutations as the most common genetic etiology in ALS/FTD has opened a new avenue of research for elucidating disease mechanisms and, ultimately, therapeutic approaches for this fatal disease. Initial observations identified decreased levels of C9orf72 protein in several brain/spinal cord regions $[8,10,20-25]$, suggesting a loss of function or haploinsufficiency as a main pathogenic mechanism. Using a variety of C9orf 72 knock out/down animal models, several mechanisms related to this theory were suggested, including aberrant autophagy, disrupted endosomal/lysosomal or endoplasmic reticulum (ER)-Golgi transport systems, and excitotoxicity $[2,26]$. Although this hypothesis still explains several aspects of C9orf72 ALS/FTD pathogenesis, other investigators have proposed a gain of toxic function, through the generation of toxic RNA repeats and dipeptide repeat proteins (DPRs) [2]. In recent years, compelling evidence indicates a role for immune dysregulation, particularly related to glial cell abnormalities, as an important mechanism underlying C9orf72 ALS/FTD pathogenesis. Here, we comprehensively review the current literature on the pathogenic roles of glial cells, focusing on microglia and astrocytes, in C9orf72 ALS/FTD as evidenced by pre-clinical and clinical studies.

\section{Overview of Pathogenic Mechanisms Underlying C9orf72 Repeat Expansion Mutation in ALS/FTD}

\subsection{Loss of Function Mechanisms}

The C9orf72 gene consists of 11 exons (including two alternate non-coding first exons$1 \mathrm{a}$ and $1 \mathrm{~b}$ ) [8]. Through alternative splicing, it can be transcribed into three transcript variants (Figure 2). The $\left(\mathrm{G}_{4} \mathrm{C}_{2}\right)_{\mathrm{n}}$ repeat expansion mutation is located in intron 1 of variants 1 and 3 , whereas in variant 2, it is located within the promoter region (Figure 2). Therefore, the repeat expansions are not incorporated into variant 2 pre-mRNA. Two protein isoforms are encoded from these transcript variants-(i) a short 222-amino acid 
protein $(24 \mathrm{KDa})$ from variant 1 and (ii) a long 481 -amino acid protein ( $54 \mathrm{KDa}$ ) from variants 2 and $3[8,9]$. Compared to variants 1 and 3, expression of variant 2 is higher in the central nervous system (CNS) relative to other tissues $[27,28]$, especially in the fetal brain and adult cerebellum and frontal cortex, and has lower expression in the hippocampus [8]. Based on immunohistochemical studies, the C9orf72 protein is mainly a neuronal cytoplasmic protein, localizing largely at the presynaptic terminals [29]. More investigation using specific antibodies for either short or long C9orf72 protein has also demonstrated that long C9orf72 protein has a diffuse cytoplasmic presence in neurons with a large antibody staining in cerebellar Purkinje cells [30]. However, the short C9orf72 protein has a very specific nuclear membrane localization in healthy neurons, with evident plasma membrane relocalization in the ALS motor neurons [30]. Cellular expression and localization of C9orf72 protein isoforms also alter throughout the development [31].

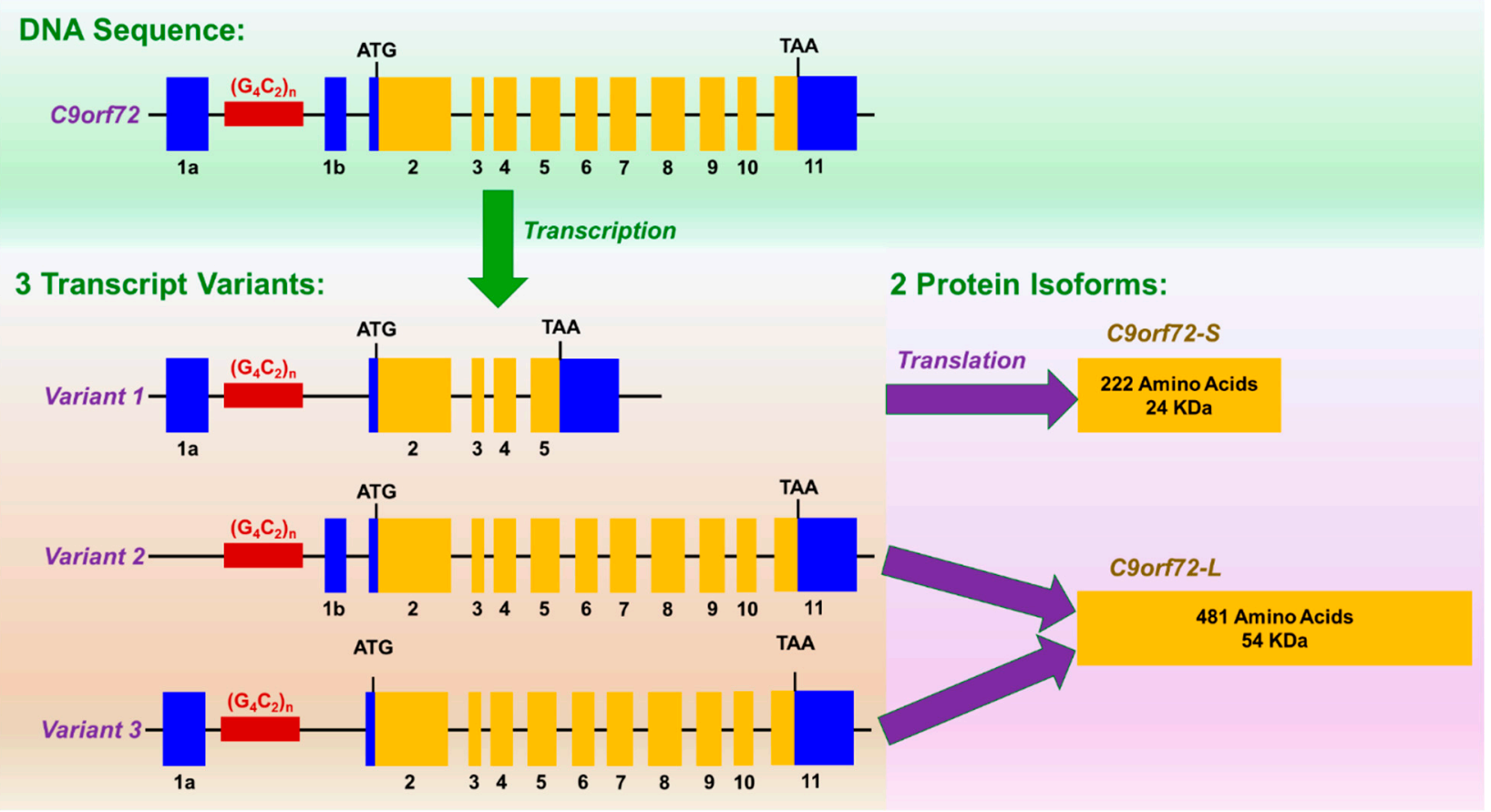

Figure 2. DNA sequence, three transcription variants, and two protein isoforms of C9orf72. The 11-exon-containing C9orf72 gene undergoes alternative splicing, producing three transcript variants. The $\left(G_{4} C_{2}\right)_{n}$ repeat expansion mutation (dark red region) is located in intron 1 of variants 1 and 3, whereas in variant 2, it is located within the promoter region. Coding exons are represented in orange and non-coding exons in blue (not to scale).

Investigations on carriers of $C 9$ orf 72 expansions have found reduced levels of $C 9$ orf 72 transcript variants (particularly variants 1 and 2) in the frontal cortex $[8,10,20-24]$, cerebellum [22-25,32], motor cortex [25], cervical spinal cord [25], induced pluripotent stem cell (iPSC)-derived neurons [25,27,33,34], and blood lymphocytes [8,20,35]. Higher levels of variant 1 were linked with prolonged survival after disease onset in expansion carriers [24]. This could be an important consideration for the development of new therapeutic approaches targeting C9orf72. Moreover, C9orf72 protein levels may be reduced in the frontal cortex in these subjects $[23,30]$. The above findings led to the initial assumption that the loss of C9orf72 protein level or function may be involved in the disease pathogenesis. Accordingly, several mechanisms have been proposed, as we discuss below.

Initial investigations revealed that C9orf72 protein shows structural homology to the differentially expressed in normal and neoplastic cells (DENN) guanine nucleotide exchange factor (GEF) proteins [36]. Functioning as a GEF, the DENN domain of C9orf72 protein is predicted to interact with Rab GTPases [36-39], which play crucial roles in both vesicular trafficking and autophagy. Immunohistochemistry of C9orf72 ALS patient motor 
neurons shows enhanced colocalization between C9orf72, Rab7, and Rab11 (involved in late endosome maturation or endosome recycling, respectively) compared with controls [40]. Additionally, decreased expression of C9orf 72 was shown to potentiate the aggregation and noxiousness of Ataxin-2 with intermediate-length polyglutamine expansions (Ataxin-2 Q30x) but not of Ataxin-2 with normal polyQ length (Ataxin-2 Q22x). Notably, Ataxin-2 Q30x is a genetic modifier of ALS/FTD [41-44]. Sellier et al. (2016) showed that depletion of C9orf72 partially deteriorated neuronal survival and synergized with Ataxin-2 Q30x toxicity to cause motor neuron degeneration, proposing a double-hit pathological contribution to ALS/FTD [45]. Consistent with the above findings, autophagy initiation was found to be disrupted in C9orf72-knockdown human cell lines or primary neurons [38,45], causing aggregation of cytoplasmic p62 and TDP-43 [38,45], both of which are histopathological characteristics of ALS/FTD. Ultimately, these findings indicate a potential disruption in autophagy as a loss-of-function mechanism for C9orf72 ALS/FTD disease pathogenesis (Figure 3).

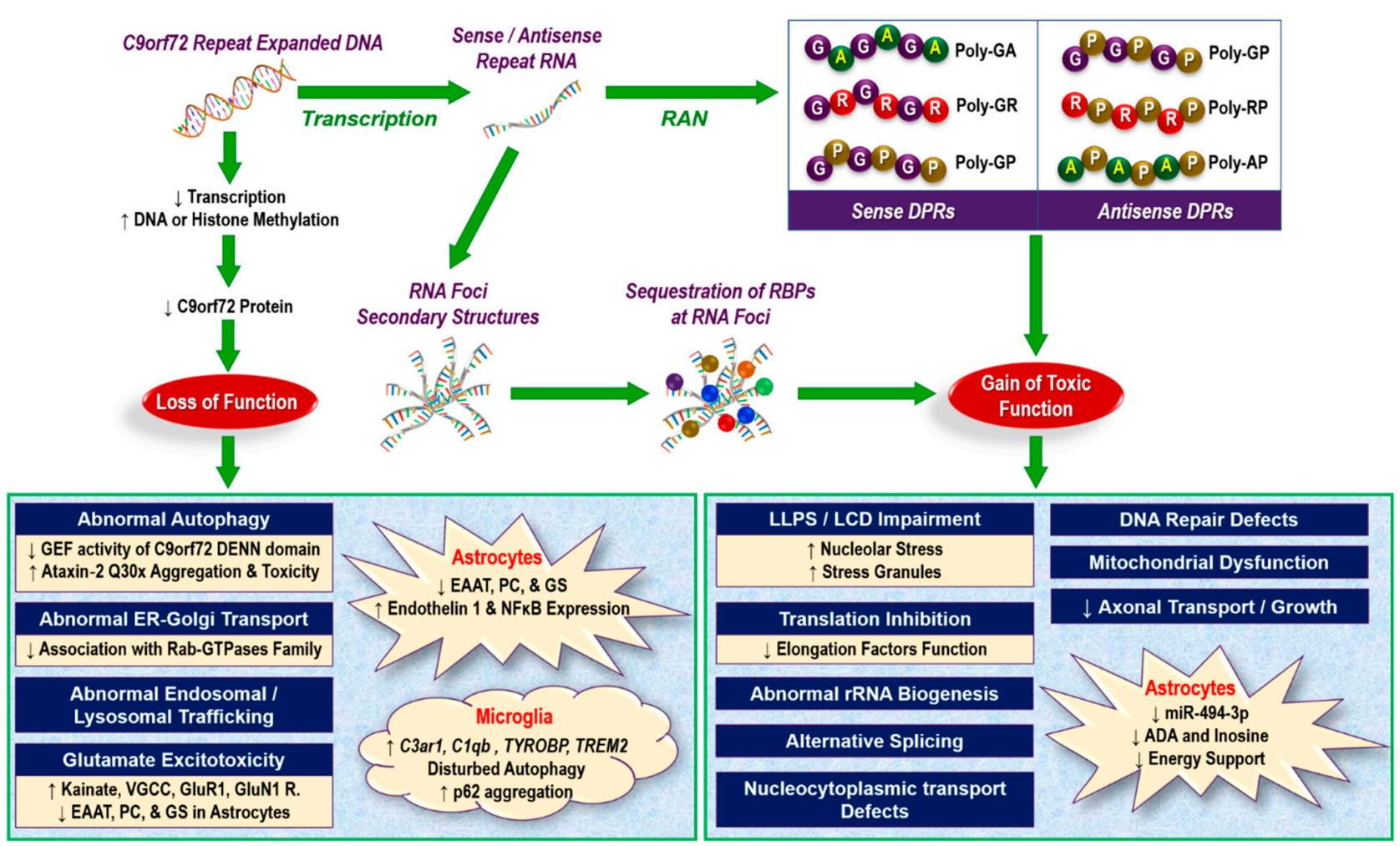

Figure 3. Pathogenic mechanisms implicated in C9orf72 ALS/FTD. Both loss and gain of function mechanisms contribute to the disease process in C9orf72 ALS/FTD. Abbreviations: ADA, adenosine deaminase; C1qb, complement component 1 , $\mathrm{Q}$ subcomponent, $\beta$ polypeptide; C3ar1, complement component 3a receptor 1; DENN, differentially expressed in normal and neoplastic cells; EAAT, excitatory amino-acid transporter; GEF, GEF, guanine nucleotide exchange factor; GluN1 $\mathrm{R}$, glutamate ionotropic receptor NMDA type subunit 1; GluR1, glutamate ionotropic receptor AMPA type subunit 1; GS, glutamine synthetase; LCD, low complexity domain; LLPS, liquid-liquid phase separation; miRNA, microRNA; PC, pyruvate carboxylase; rRNA, ribosomal RNA; TREM2, triggering receptor expressed on myeloid Cells 2; TYROBP, tyrosine kinase binding protein; and VGCC, voltage-gated calcium channel.

Another potential loss-of-function mechanism is that of disrupted lysosomal degradation. Reduced endocytosis and impaired endosomal/lysosomal trafficking have been demonstrated in C9orf72 knockdown cell lines [40], bone marrow-derived macrophage and microglia from C9orf $72^{-/-}$mice [46], and C9orf72 ALS patient-derived fibroblasts and neurons [47]. C9orf72 protein has been shown to be localized primarily to early endosomes in iPSC-derived motor neurons [34,48]. Accordingly, fewer lysosomes and reduced vesicular trafficking are observed in iPSC-derived motor neurons from C9orf72 ALS patients [34]. 
Mannose-6-phosphate receptors (M6PRs) are a group of transmembrane glycoproteins that target lysosomal enzymes to lysosomes. It has been shown that these receptors are affected by C9orf72 mutations [34] because they cause clustering of these receptors, slowing their movement [34], and their intracytoplasmic mislocalization (rather than normal perinuclear localization) in C9orf72 ALS/FTD fibroblasts [47]. Therefore, these changes related to C9orf72 mutation disrupt lysosomal degradation. Accumulating evidence also indicates that C9orf72 repeat expansion mutation may negatively affect the ER-Golgi transport system $[49,50]$. C9orf 72 knockdown impairs endocytic trafficking from the plasma membrane to the Golgi [40,47] (Figure 3).

Neuronal hyperexcitability and related excitotoxicity secondary to aberrant glutamatergic transmission have been suggested as the underlying mechanisms for ALS/FTD pathogenesis [51]. Regulated glutamatergic transmission is a complex process, depending on extracellular glutamate levels, reuptake, and re-synthesis, in addition to activation of postsynaptic glutamate receptors (including $N$-methyl-D-aspartate (NMDA) and nonNMDA such as $\alpha$-amino-3-hydroxy-5-methyl-4-isoxazolepropionic acid (AMPA) receptors) and related intracellular calcium overload. Accumulating evidence has suggested that this system is involved in the pathogenesis of ALS. However, the only modest effect of the glutamate release inhibitor, riluzole, on the survival of ALS patients indicates that this pathway is not the sole mechanism for ALS pathogenesis. Nevertheless, in recent years, investigators have tried to elaborate a link between ALS/FTD gene mutations, including C9orf72 repeat expansions, and neuronal hyperexcitability/excitotoxicity mechanisms. The expression of kainate receptors and voltage-gated $\mathrm{Ca}^{2+}$ channels in iPSC-derived motor neurons, cell surface levels of the NMDA receptor GluN1 and the AMPA receptor GluR1 on neurites, and dendritic spines of iMNs from C9orf72 ALS/FTD patients are found to be markedly elevated compared to controls [34,52,53]. Glutamate receptors also accumulate at postsynaptic densities in these neurons [34]. Additionally, the post-mortem anterior horn of cervical spinal cord sections from C9orf72 ALS patients have increased GluR1 expression [53]. High levels of glutamate receptors can lead to hyperexcitability and cell death as a result of glutamate hyperactivation. Accordingly, activation of Kv7 potassium channels was found to improve the survival of C9orf72 patient-derived and C9orf72-deficient iMNs [34]. More recent studies demonstrated that iPSC-derived motor neurons with C9orf72 mutation had elevated $\mathrm{Ca}^{2+}$-permeable AMPAR expression and selective motor neuron susceptibility to excitotoxicity [53], which was eliminated by CRISPR/Cas9-mediated correction of the C9orf72 mutation in these neurons [53]. Other investigators [25] also found that the C9orf72 repeat expansion mutation causes nuclear RNA foci sequestering of the enzyme adenosine deaminase acting on RNA 2 (ADAR2), which catalyzes GluR2 editing, linking the C9orf72 mutation to excitotoxicity. Given the important role of ADAR2 in double-stranded RNA editing, mislocalization of ADAR2, as shown in a recent study on transgenic $\left(\mathrm{G}_{4} \mathrm{C}_{2}\right)_{149}$ mice, can have detrimental effects on RNA editing [54]. Consistently, ADAR2 knockdown in mice motor neurons slows the rate of degeneration and reduces the loss of neuromuscular synapses in these cells [55]. Agents such as an anticoagulation-deficient form of activated protein C (3K3A-APC), which can lower glutamate receptor levels, are able to decrease excitotoxicity and rescue proteostasis in vivo in both C9orf72 gain- and loss-of-function mouse models [56].

\subsection{Challenges in Loss-of-Function Theory}

Although based on the above-mentioned studies it was originally proposed that loss of function is the main mechanism underlying the pathology of C9orf72 repeat expansion mutation in ALS/FTD [34], subsequent studies have challenged this hypothesis. An important initial observation was that neural-specific ablation of C9orf72 in conditional C9orf $72^{-/-}$mice did not induce motor neuron degeneration, defects in motor function, or alter survival [57]. Moreover, several studies have shown that ubiquitous [46,58-62] or CRISPR/Cas9-mediated [61,63] C9orf72 knockouts throughout development resulted in dysregulation of the immune system in homozygous mice. These mice exhibited a 
variety of manifestations, including significant changes in myeloid and/or lymphoid cell populations in lymph nodes and spleen, higher levels of inflammatory cytokines, cervical/systemic lymphadenopathy, splenomegaly, glumerulonephropathy, decreased body weight, malignancies, and elevated titers of autoimmune antibodies. This severe phenotype, however, was not observed in haploinsufficiency models of C9orf72 [64]. Next, studies surveyed the C9orf72 locus using cap analysis of gene expression sequence data (CAGEseq) and found high gene expression in $\mathrm{CD}^{14+}$ monocytes, important cells in innate and adaptive immunity [28]. Taken the above challenges together with the role of $C 9$ orf 72 in signaling pathways previously implicated in ALS/FTD [64,65], C9orf72 haploinsufficiency combined with gain-of-function mechanisms and/or mutations in other modifier genes (for instance, Ataxin-2 Q30x, as discussed above) are possible mechanisms underlying the ALS/FTD pathogenesis.

\subsection{Gain-of-Function Mechanisms}

The dominant inheritance pattern of C9orf72 ALS/FTD, the nonappearance of ALS or FTD patients with missense mutations or null alleles in the C9orf 72 gene, and the absence of a neurodegeneration phenotype in most of $C 90 \mathrm{orf} 72^{-/-}$mice (as discussed above) have argued against the loss of $C 9$ orf 72 function theory as the single mechanism of the disease. In fact, more recent evidence points to the gain of toxic functions as the major mechanism underlying neurodegeneration in C9orf72 ALS/FTD (Figure 3). Accordingly, the adenoassociated virus (AAV)-mediated delivery of a construct that expresses $\mathrm{G}_{4} \mathrm{C}_{2}$ repeats can cause neurodegeneration in mice brain [66]. Several mechanisms have been proposed to explain the toxic gain of function in C9orf72 ALS/FTD.

When the C9orf72 repeat expansion mutation was initially identified in C9orf72 ALS/FTD patients, it was also found that widespread intranuclear RNA foci containing the $\mathrm{G}_{4} \mathrm{C}_{2}$ repeats accumulate in both the brain and spinal cord of these patients [8]. This observation provided a second possible disease mechanism involving a toxic gain of function by repeat-containing RNA. It was also shown that $C 9$ orf 72 could be bidirectionally transcribed to the sense $G_{4} C_{2}$ or antisense $C_{4} G_{2}$ RNA transcript, which can sequester as RNA foci in the affected cells [67-69]. These RNA foci were identified in fibroblasts $[25,33,70]$ and motor neurons derived from fibroblast-derived iPSCs from C9orf 72 ALS patients [25,33,70,71]. A similar mechanism was previously suggested in other neuromuscular disorders, including myotonic dystrophy type I, myotonic dystrophy type II, fragile X-associated tremor and ataxia syndrome, and some types of spinocerebellar ataxia, all of which are due to the expansion of nucleotide repeats in non-coding regions [72]. The exact mechanisms by which intranuclear RNA foci cause neurotoxicity/degeneration in ASL/FTD is not completely understood; however, the following mechanisms have been suggested:

- $\quad$ Binding of RNA foci to RNA-binding proteins (RBPs), forming neurotoxic aggregates [26];

- Formation of G-quadruplex and R-loop structures [73-80], causing nucleolar stress [77], genomic instability, and an increased DNA double-stranded break [81,82];

- Formation of other secondary structures such as hairpins [76,77], RNA duplexes, and i-motifs and DNA-RNA heteroduplexes [83-85], which may be toxic for neuronal cells.

One of the most intriguing pathologic models that has been recently proposed as the primary pathology for C9orf72 ALS/FTD is the formation of dipeptide repeat proteins (DPRs). It was shown that the repeat-containing C9orf72 transcripts can escape the nucleus and be attached by ribosomal complexes, thereby boosting repeat-associated nonATG-dependent (RAN) translation that leads to toxic aggregation of polydipeptides or DPRs [77] (Figure 3). The expanded domains in C9orf72 can undergo RAN translation in all six possible reading frames and across both sense and anti-sense RNA; this results in the generation of five different DPRs (Figure 3) [86]. Overexpression of each DPRs in various cell models [69,87-93], zebrafish [94-96], Drosophila [87,97,98], and mice [99,100] have resulted in neurotoxicity and revealed the involvement of several downstream pathways. Among the DPRs, poly-glycine-arginine (poly-GR) and poly-proline-arginine (poly-PR) were the most neurotoxic, and poly-glycine-alanine (poly-GA) exerted less 
toxicity $[20,87-89,92,101-103]$. Other DPRs, such as poly-proline-alanine (poly-PA) and poly-glycine-proline (poly-GP), had less or no toxicity [87,98,102]. Administration of synthetic poly-PR and poly-GR into cultured human astrocytes [104] and poly-GA and poly-GR into primary neurons [105] also caused cellular toxicity. It was further shown that poly-(GA) ${ }_{15}$ fibrillates rapidly and eventually forms toxic flat, ribbon-type fibrils, as demonstrated by transmission electron microscopy and atomic force microscopy [93].

Given the toxic nature of DPRs, these polydipeptides probably affect a variety of downstream pathways that eventually lead to neuronal cell death, which include the following (Figure 3):

- Impairment of liquid-liquid phase separation (LLPS) through interaction with low complexity domain (LCD) proteins in nucleoli and stress granules [97,106-108]. LLPS of key protein and nucleic acid scaffolds play an important role in the biogenesis of diverse membrane-less organelles (e.g., P granules and stress granules in the cytoplasm and nucleoli and paraspeckles in the nucleus) that are essential organizers of subcellular biochemistry, controlling the information processing from genotype to phenotype [109];

- Binding with and thereby inhibiting translation initiation and elongation factors, causing neurotoxicity [89,110-114];

- Impairment of ribosomal RNA maturation and abnormal splicing. A pioneering study by Kwon et al. (2014) indicated that exogenous administration of synthetic poly-(GR) $)_{20}$ and poly-(PR $)_{20}$ to human astrocytes led to their accumulation in the nucleus and binding to the LCD of hnRNPA2, causing aberrant pre-mRNA splicing and impaired rRNA biogenesis [104];

- Mitochondrial dysfunction [115,116];

- Binding with nuclear pore complex proteins, causing a defect in nucleocytoplasmic trafficking $[25,30,104,117-119]$, and thereby neurotoxicity.

\section{Neuroinflammation in C9orf72 ALS/FTD: Glial Cells Dysfunction}

As previously described, the C9orf72 gene can be expressed in different cell types other than motor neurons and most significantly in the immune system [28,61]. Neuroinflammation is an extremely complex process involving glial cells. Despite its complexity, it is a well-orchestrated symphony of cross talks between different cell types via cytokines and other molecules. Disturbance of this highly evolved function may lead to detrimental effects on the nervous system function [120]. Here, we will discuss the role of glial cells, focusing on microglia and astrocytes and chronic neuroinflammation in the C9orf72-related ALS/FTD.

\subsection{Glial Cells in the Central Nervous System}

Although the CNS is traditionally considered an "immunologically privileged site" due to the blood-brain barrier, immunological reactions are still occurring within the CNS by different mechanisms despite the absence of leukocytes and antibodies. CNS homeostasis mainly is regulated by innate immunity [121]. The key mediators of immune reactions within the CNS are glial cells, which are the most abundant cell type in the CNS. Glial cells consist of microglia, astrocytes, and oligodendrocytes [121]. Here, we mainly focus on microglia and astrocytes. Microglia are the resident mono-phagocytic cells in the CNS [122]. During embryogenesis will spread in the brain after being derived from myeloid precursor cells and later would make up to $12 \%$ of adult CNS cells [123]. Microglia are generally the first cell type to get activated in response to insults and they are the most motile cell types in CNS [120]. Activated microglia have various physiologic functions including cellular maintenance, innate immunity, the release of trophic and anti-inflammatory factors, and expediting stem cell migration to the site of injury or inflammation [124-126]. Microglia morphology alters in response to certain stimuli (e.g., brain injury or immunological stimuli) from resting ramified microglia to an amoeboid form that presents an upregulated series of surface molecules, receptors, and new intracellular proteins/enzymes such as 
inducible nitric oxide synthase (NOS) and cyclo-oxygenase $2[121,125]$. Astrocytes, on the other hand, are the most abundant glial cells in the CNS. They play variable vital roles, including but not limited to balancing key elements in ionic homeostasis, buffering the action of neurotransmitters (particularly excitatory ones), and secreting growth factors and nutrients [127]. They also contribute to regulating blood-brain barrier function, synaptic plasticity, and neuroprotection [128,129]. Astrocytes generally produce multiple extensions from their cell body and make endfeet at their extended end. Astrocyte's extensions interact with other cells, including blood vessel's endothelial cells and pericytes, helping to build the blood-brain barrier [128,130]. Activated astrocytes release trophic factors to help neuronal survival in response to injury. Reactive astrocytes can be divided into A1 and A2 type phenotypically, parallel to what is known for reactive macrophages categorized as M1 and M2. Gene transcriptome analyses demonstrated that A1 astrocytes express inflammatory cytokines and trigger cascades that are harmful and destructive to synapses, while A2 astrocytes express neurotrophic factors and help synapse repair [131]. It seems that different types of injuries may determine which kind of reactive astrocytes would dominate the response. For example, ischemic injuries to CNS provoke an A2 response, but inflammatory insults will trigger A1 reactive astrocytes [131,132]. Generally, under chronic stress conditions such as progressive neurodegeneration, both microglia and astrocytes remain activated, which leads to detrimental outcomes on neuronal cell function due to excess production of different neurotoxic cytokines (e.g., interleukin [IL]-1 $\beta$ and tumor necrosis factor $[\mathrm{TNF}]-\alpha$ ) and noxious molecules (e.g., excess $\mathrm{NO}$ and superoxide anions) (Figure 4) [121].

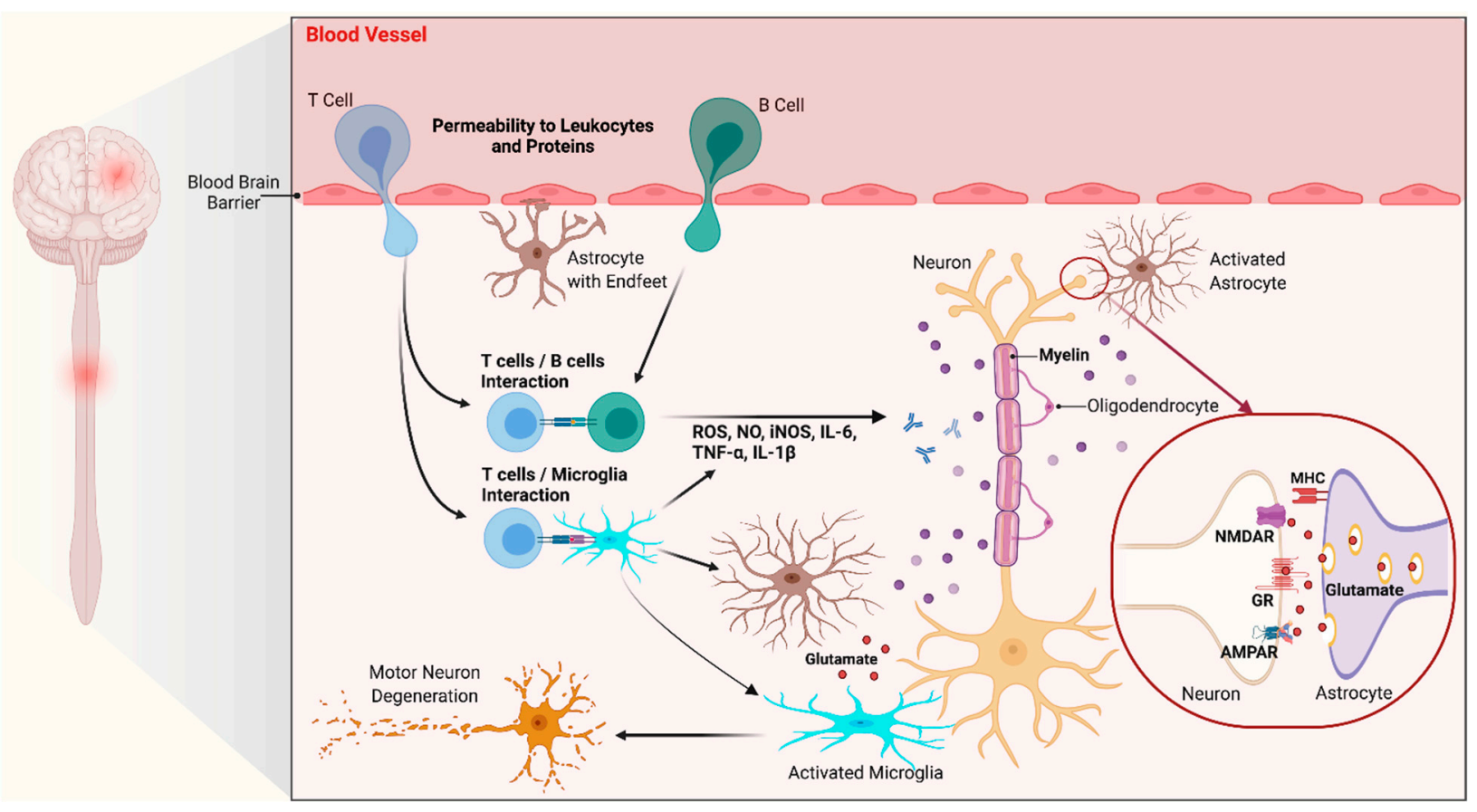

Figure 4. Pathogenic mechanisms underlying glial cell toxicity in neurodegeneration. Microglia and astrocytes become overactivated and lead to neurotoxicity through several mechanisms. Activated microglia and astrocytes produce excess noxious pro-inflammatory factors, such as nitric oxide (NO), reactive oxygen species (ROS, e.g., $\mathrm{H}_{2} \mathrm{O}_{2}$ and $\mathrm{ONOO}^{-}$), several cytokines (e.g., interleukin [IL]-1 $\beta$, IL-6, and tumor necrosis factor [TNF]- $\alpha$ ), and glutamate. AMPAR, $\alpha$-amino-3-hydroxy5-methyl-4-isoxazolepropionic acid (AMPA) receptor; GR, glutamate receptor; MHC, major histocompatibility complex; and NMDAR, $N$-methyl-D-aspartate (NMDA) receptor.

\subsection{A Role for Glial Cells in C9orf72 ALS/FTD}

Although several studies investigating ubiquitous [46,58-62] or CRISPR/Cas9mediated $[61,63]$ C9orf72 knockout in homozygous mice throughout development have 
inconsistently reported on motor neurons' involvement in these animals, one unequivocal and yet crucial result has been found-a dysregulation of the immune system exists in homozygous mice (Table 1). This is evidenced by altered myeloid/lymphoid cell populations in lymph nodes/spleen, elevated inflammatory cytokines/autoimmune antibodies, cervical/systemic lymphadenopathy, splenomegaly, and malignancies. High C9orf72 gene expression was also found in $\mathrm{CD}^{14+}$ monocytes [28]. These observations support that (i) complete loss of C9orf72 results in a systemic pro-inflammatory state possibly driven by myeloid cells in the spleen and lymph nodes and (ii) haploinsufficiency may be enough to affect myeloid cell function and systemic immunity in mice [133]. Additionally, C9orf72-/mice exhibit age-related neuroinflammation [67].

Table 1. Immune system dysregulation phenotypes in homozygotes in mouse models of C9orf72 loss of function.

\begin{tabular}{|c|c|c|c|c|}
\hline C9orf72 Knockout Method & Immune System & Motor & Cognition/Behavior & Ref \\
\hline Non-conditional exons 2-6 & $\begin{array}{l}\text { Splenomegaly and } \\
\text { cervical lymphadenopathy }\end{array}$ & $\begin{array}{l}\text { Mild motor deficits only on a } \\
\text { rotarod assay at } 12 \text { months }\end{array}$ & $\begin{array}{l}\text { Mild social interaction and } \\
\text { social recognition deficits }\end{array}$ & [58] \\
\hline Non-conditional full gene & $\begin{array}{c}\text { Splenomegaly, systemic } \\
\text { lymphadenopathy, } \\
\text { glumerulonephropathy, and } \uparrow \text { serum } \\
\text { IL-12, IL-17a, IL-10, TNF- } \alpha \text {, plasma } \\
\text { cells, and activated T cells. }\end{array}$ & $\begin{array}{l}\text { Mild motor deficits, tremor, } \\
\text { and rigidity at } 40 \text { weeks }\end{array}$ & NR & [59] \\
\hline $\begin{array}{l}\text { Non-conditional exons 2-6 or } \\
\text { zinc finger deletion }\end{array}$ & $\begin{array}{c}\text { Splenomegaly and } \\
\text { cervical lymphadenopathy }\end{array}$ & Normal function & NR & [60] \\
\hline NR, all tissues full knockout & $\begin{array}{l}\text { Splenomegaly, cervical } \\
\text { lymphadenopathy, and } \\
\text { B-cell lymphomas }\end{array}$ & Normal function & NR & [46] \\
\hline $\begin{array}{c}\text { Non-conditional exons 2-6 } \\
\text { knockouts in a C57BL/6 } \\
\text { background or CRISPR/Cas9 }\end{array}$ & $\begin{array}{c}\text { Splenomegaly, cervical } \\
\text { lymphadenopathy, hepatomegaly, } \\
\text { and } \uparrow \text { serum IL-22, IL-28, IL-23, IL-6, } \\
\text { MCP-1, IL-31, IL-5, IL-10, IL-1 } \beta \text {, } \\
\text { IL-15/IL-15R, IFN } \gamma \text {, IL-3, GM-CSF, } \\
\text { IL-17A, IFN } \alpha, \text { MIP-1B, LIF, GRO } \alpha\end{array}$ & NR & NR & [61] \\
\hline $\begin{array}{l}\text { Non-conditional } \\
\text { CRISPR/Cas9 }\end{array}$ & $\begin{array}{c}\text { Splenomegaly and } \\
\text { systemic lymphadenopathy }\end{array}$ & NR & NR & [63] \\
\hline Non-conditional exons 2-6 & Splenomegaly & NR & Lethargy & [62] \\
\hline Non-conditional exons 2-6 & $\begin{array}{c}\text { Splenomegaly, systemic } \\
\text { lymphadenopathy, and } \uparrow \text { serum IL-6 }\end{array}$ & NR & NR & [134] \\
\hline Non-conditional exons 2-6 & Splenomegaly & Normal function at 3 months & NR & {$[135]$} \\
\hline
\end{tabular}

GM-CSF, granulocyte-macrophage colony-stimulating factor; GRO $\alpha$, growth-regulated oncogene $\alpha$; IL, interleukin; LIF, leukemia inhibitory factor; MIP, macrophage inflammatory protein; NR, not reported; TNF, tumor necrosis factor; and $\uparrow$, increased.

Given the fact that neuroinflammation (e.g., glial activation) has been indicated in the pathophysiology of a variety of neurodegenerative diseases [121], and even though there is still debate whether it is a cause or a consequence of these diseases, the above findings have raised an important question: does immune system dysregulation, and in particular glial cells dysfunction, contribute to the C9orf72 ALS/FTD pathogenesis?

\subsubsection{Evidence for Gliosis in C9orf72 ALS/FTD}

To address the involvement of glial cells in the C9orf72 ALS/FTD pathogenesis, a wide range of studies with different methodology and outcome measurements has been conducted (Table 2). For instance, RNA expression analyses have found that signaling pathways related to interferon (IFN) $-\gamma$, IL- $1 \beta$, complements, and antigen presentation system are markedly upregulated in the brains of C9orf72 ALS patients compared to sporadic ALS cases [60,136]. Increased glial fibrillary acidic protein (GFAP) expression, an indicator of astrogliosis, has been detected in the frontal cortex and cerebrospinal fluid (CSF) of FTD patients [137,138] and C9orf72 $\left(\mathrm{G}_{4} \mathrm{C}_{2}\right)_{500}$ BAC transgenic mice [139]. Moreover, astrocytes exert higher glucose metabolism in C9orf72 ALS patients compared 
to other ALS cases [140]. However, C9orf $72^{-/}$mice do not exert any elevated GFAP immunoreactivity [57], suggesting that absent C9orf72 does not lead to astrogliosis.

Table 2. Evidence of gliosis in C9orf72 ALS/FTD.

\begin{tabular}{|c|c|c|c|}
\hline Species & Region & Results & Ref \\
\hline C9orf $72^{-1-}$ mice & $\begin{array}{l}\text { Brain } \\
\text { Isolated spinal cord microglia }\end{array}$ & $\begin{array}{l}\uparrow \text { LysoTracker- and Lamp1-positive structures } \\
\text { in microglia } \\
\uparrow \text { IL-6 and IL-1b levels }\end{array}$ & {$[60]$} \\
\hline C9orf72-/- mice & Brain and spinal cord & No change in GFAP and Iba1 staining at 18 months & [57] \\
\hline$\left(\mathrm{G}_{4} \mathrm{C}_{2}\right)_{500} \mathrm{BAC}$ transgenic mice & $\begin{array}{l}\text { Hippocampus } \\
\text { Motor cortex (layers I-III \& layer V) } \\
\text { and hippocampus }\end{array}$ & $\begin{array}{l}\uparrow \text { Iba1 staining in acute end-stage ( } 20-40 \text { weeks) mice } \\
\uparrow \text { GFAP staining in acute end-stage ( } 20-40 \text { weeks) mice }\end{array}$ & [139] \\
\hline $\begin{array}{l}\text { Transgenic mice expressing } \\
\text { poly-(GA) })_{149}\end{array}$ & Spinal cord & $\begin{array}{c}\uparrow \text { CD68 and Iba1 immunostaining and mRNA } \\
\text { expression at six months, but little at one month; No } \\
\text { change in GFAP immunostaining and } \\
\text { mRNA expression }\end{array}$ & {$[100]$} \\
\hline $\begin{array}{l}\text { Transgenic mice expressing } \\
\text { poly-(GA) })_{50}\end{array}$ & $\begin{array}{l}\text { Brain } \\
\text { Cortex, motor cortex, and hippocampus }\end{array}$ & $\begin{array}{l}\text { 个 GFAP mRNA expression, but No change in Iba1 } \\
\text { mRNA expression at six months } \\
\text { 个 GFAP immunostaining and immunohistochemistry }\end{array}$ & [99] \\
\hline $\begin{array}{l}\text { Transgenic mice expressing } \\
\text { poly-(GR) })_{100}\end{array}$ & Brain & $\begin{array}{l}\uparrow \text { GFAP and Iba } 1 \text { mRNA expression and } \\
\text { immunostaining at } 1.5>3>6 \text { months }\end{array}$ & [114] \\
\hline C9orf72 ALS patients & $\begin{array}{l}\text { Postmortem motor cortex and } \\
\text { spinal cord }\end{array}$ & $\uparrow$ Iba1 and Lamp1 immunostaining & {$[60]$} \\
\hline C9orf72 ALS patients & $\begin{array}{l}\text { Postmortem pyramidal tract at all levels } \\
\text { (white matter underlying motor cortex, } \\
\text { mid-crus cerebri, medullary pyramids, } \\
\text { and lateral and anterior } \\
\text { corticospinal tracts) }\end{array}$ & $\uparrow$ CD68 immunohistochemistry & {$[4]$} \\
\hline C9orf72 ALS patients & $\begin{array}{l}\text { Postmortem white matter of the medulla } \\
\text { and the motor cortex }\end{array}$ & $\uparrow$ CD68 and Iba1 immunostaining & {$[141]$} \\
\hline C9orf72 ALS patients & Postmortem corpus callosum & $\begin{array}{l}\uparrow \text { CD68 immunohistochemistry in the body more than } \\
\text { genu or splenium of the callosum }\end{array}$ & {$[142]$} \\
\hline C9orf72 FTD patients & Plasma & $\begin{array}{l}\text { No change in GFAP concentration between pre- and } \\
\text { symptomatic cases and non-carriers }\end{array}$ & {$[143]$} \\
\hline C9orf72 ALS patients & $\begin{array}{l}{\left[{ }^{18} \mathrm{~F}\right] \mathrm{FDG} \text { PET in C9orf72 ALS vs. }} \\
\text { sporadic ALS }\end{array}$ & $\begin{array}{c}\downarrow \text { Metabolism in the anterior and posterior cingulate } \\
\text { cortex, insula, caudate and thalamus, the left frontal } \\
\text { and superior temporal cortex, } \\
\uparrow \text { Metabolism in the midbrain, bilateral occipital cortex, } \\
\text { globus pallidus, and left inferior temporal cortex }\end{array}$ & {$[140]$} \\
\hline
\end{tabular}

ALS, amyotrophic lateral sclerosis; FTD, frontotempoal dementia; GFAP, glial fibrillary acidic protein; Iba1, Ionized calcium-binding adaptor molecule 1; IL, interleukin; $\uparrow$, increased; and $\downarrow$, decreased.

Microglial hyperactivation is also found in C9orf72 ALS/FTD post-mortem brain regions, as evidenced by altered cell morphology and increased markers of gliosis (ionized calcium-binding adaptor molecule 1 (Iba1) and cluster of differentiation 68 (CD68) immunoreactivity), compared to sporadic ALS/FTD cases [4,141,142] (Table 2). CD68 is a lysosomal membrane glycoprotein in mononuclear phagocyte lineage cells, such as macrophages, microglia, osteoclasts, and myeloid dendritic cells [144]. It is widely used as an indicator of phagocytic activity of microglia $[145,146]$, although it can also be expressed on resting microglia [147]. Iba1 is a 17kDa protein that is expressed in all subtypes of microglia, contributing to microglia motility and phagocytosis, and it is associated with microglial activity [148-151].

Activated microglia were also found to have enlarged lysosomes compared to sporadic ALS cases [60]; the pathologic aspects of this finding are yet to be identified. Further studies are still needed to delineate the relation of gliosis to different stages of the disease process, given the fact that either astro- or micro-gliosis could act as both pro- and antiinflammatory. Accordingly, an interesting study [100] showed that both elevated CD68 and Iba1 expression are detected at six months of age in the spinal cord of transgenic mice that 
express poly-(GA) ${ }_{149}$ specifically in neurons [100]. Notably, glial hyperactivation was not present in other brain regions where the neurons did not have poly-GA pathology, and at the time, there was no significant detectable neuronal loss [100]. Notably, at this point, these mice exhibited an enhanced TDP-43 phosphorylation without translocation/inclusions or mild behavioral deficits [100]. When mice were evaluated at one month of age, on the other hand, they did not have the elevation of Iba1 but already had an elevated CD68 expression [100]. These findings indicated two important points-(i) microglial activation might precede severe neuronal dysfunction and (ii) enhanced microglial CD68 expression may precede increased Iba1 expression. Another study showed that six-monthold poly-(GA) 50 mice did not have elevated Iba1 levels or TDP-43 pathology, but they had behavioral impairments and neurodegeneration [99]. A more recent study also showed that 1.5-month-old poly-(GR) 100 mice had elevated cortical/hippocampal lba1 expression, brain atrophy, and neuronal loss, without TDP-43 pathology [114]. The results of these studies may indicate that, firstly, neuron-glia communication might participate in the activation of microglia and, secondly, length or type of DPR and additional factors (e.g., TDP-43 phosphorylation) might differentially control microglial activation in the C9orf72 pathology.

\subsubsection{C9orf72 Pathologic Hallmarks in Glial Cells}

Another important issue in the study of glial cells in C9orf72 pathology is to answer whether these cells also exhibit characteristic C9orf72 pathology (i.e., RNA foci or DPRs) similar to the affected neurons. Notably, studies investigating the presence of RNA foci or DPRs in glial cells of C9orf72 ALS/FTD cases or in animal models have consistently demonstrated either no or low levels of RNA foci $[67,70,71,152,153]$ and DPRs $[67,86,154,155]$ in different CNS regions compared to neurons. Moreover, in contrast to neurons that exhibit both intranuclear and intracytoplasmic RNA foci, glial cells show only intranuclear RNA foci $[70,152]$. AAV-mediated DPR expression in mice results in the accumulation of DPRs in neurons but not glial cells [66]. Further studies are needed to explain why the levels of RNA foci and DPRs are lower in glial cells. For instance, this might be due to less expression of the C9orf72 repeated expansion mutation, less expression of RNA binding proteins involved in RNA aggregates, better C9orf72 repeated expansion containing RNA, less RAN clearance of C9orf72 repeated expansion containing RNA [156], less cytosolic translocation of translation, or finally, enhanced degradation of DPRs prior to their accumulation. Another possibility is that DPRs are not produced within glial cells but are instead secreted by neurons and then transferred to glial cells through possible cell-to-cell communication between neurons and glia [157]. Given the fact that glial cells undergo extensive proliferation and gliosis [158,159], this may prevent/decrease generation or dilute the level of already present RNA foci or DPRs in these cells and may provide another explanation for why levels of RNA foci or DPRs are less in glial cells compared to C9orf72 neurons. In contrast to RNA foci and DPRs, other pathologic features of C9orf72 repeat expansion, including TDP-43 and p62 aggregates, are present in glial cells [3-6] and even in oligodendrocytes [160-162] of C9orf72 ALS/FTD cases.

\subsubsection{Toxic Effects of C9orf72 Glial Cells}

Recent investigations have indicated that glial cells themselves may mediate neurotoxicity in C9orf72 ALS/FTD [163]. In a study using murine embryonic stem cell-derived motor neurons, neuronal death was observed within four days of co-culture with fibroblastderived astrocytes from C9orf72 ALS cases [163]. Additionally, when the culture medium was partially replaced with the control astrocyte conditioned medium (ACM), the ongoing neuronal cell death was not inhibited [163]. Another study also revealed increased neuronal cell death in iPSC-derived motor neurons from either control or C9orf72 ALS patients five days after culturing in C9orf72 ALS ACM [164]. Moreover, it was demonstrated that induced astrocytes from C9orf72 ALS cases can release extracellular vesicles promoting motor neuron toxicity [165]. The microRNA (miRNA) profile of extracellular vesicles secreted by C9orf72 ALS astrocytes was found to have a unique set of 13 dysregulated 
miRNAs involved in axonal guidance and maintenance [165]. Among these, miR-494-3p was identified as the most dysregulated miRNA, and its reduced levels in the C9orf72 astrocytes-secreted extracellular vesicles were correlated with dramatic consequences on axonal/neurite length and motor neuron survival in vitro and in the postmortem ALS corticospinal tract [165]. Accordingly, treatment with a miR-494-3p mimic completely rescued neurite length and the number of nodes per cell, accompanied by a significant $20-25 \%$ increase in motor neuron survival [165]. The addition of the ACM from the same C9orf72 astrocytes also slightly affected neuronal cell survival [165]. Altogether, these studies pinpoint three important things-(i) a possible underlying gain-of-toxic-function mechanism by the C9orf72 astrocytes in ALS/FTD pathogenesis, (ii) a level of toxicity related to possible direct physical communication between C9orf 72 astrocytes and neurons or secretion of possible neurotoxic agents from C9orf72 astrocytes, and (iii) an impaired capacity of C9orf72 astrocytes to support neurons. In agreement with the latter, impaired biogenesis of extracellular vesicles $[47,165]$ or abnormal autophagy initiation [164] in C9orf72 ALS/FTD motor neurons are linked to C9orf72 astrocytes.

Defective adenosine triphosphate (ATP) metabolism and bioenergetic deficits are also found in the CNS of C9orf72 ALS/FTD patients [166-168]. Deamination of adenosine by adenosine deaminase (ADA) generates inosine and the established pathways for nicotinamide adenine dinucleotide (NADH)-based energy production from both inosine and adenosine is through metabolism to ribose-phosphate and finally glycolysis [166,167]. A recent study found a significantly decreased ADA protein level and mRNA expression in C9orf72 fibroblasts, induced astrocytes, and induced neurons from C9orf72 ALS/FTD cases [166]. Notably, C9orf72 ALS-induced astrocytes were more susceptible to adenosineinduced cell loss than control induced astrocytes, whereas inosine supplementation produced very little cell loss in any lines [166]. Additionally, it was found that defective ATP and purine metabolism due to ADA deficiency led to glial overactivation and neuroinflammation and diminished nutritional support for neurons by C9orf72 astrocytes [166]. Loss of metabolic flexibility, involving defects in adenosine, fructose, and glycogen metabolism, and disturbances in the membrane transport of mitochondrial energy substrates are present in C9orf72-induced astrocytes, contributing to increased starvation-induced toxicity in these cells [167].

In addition to the above-mentioned gain-of-function mechanisms, other investigators have proposed haploinsufficiency as a possible loss-of-function mechanism underlying the glial cell-mediated toxicity in C9orf72 ALS/FTD. One of the important actions of astrocytes is buffering the excitatory neurotransmitter glutamate in the synaptic cleft, preventing excess glutamate neurotoxicity. Notably, siRNA-mediated knockdown of both C9orf72 protein isoforms in U87 glioblastoma cells and normal human astrocytes is shown to reduce expression of excitatory amino-acid transporter (EAAT)- 1 and -2, pyruvate carboxylase, and glutamine synthetase in astrocytes, and intracellular glutamate accumulation [169], providing evidence for knockdown astrocyte-related disturbed glutamate synthesis, uptake, and conversion into glutamine, which ultimately can cause glutamate excitotoxicity. These cells also exerted accumulation of p62 inclusions [169]. It was also shown that the expression of endothelin 1, a negative regulator of EAAT2, was increased secondary to an increased expression of nuclear factor kappa-light-chain-enhancer of activated B cells (NFkBs) due to knockdown of C9orf72 [169]. Elevated endothelin 1 levels secreted by activated astrocytes can initiate inflammatory cascades (such as upregulation of inducible NOS and excess NO production), which cause toxicity in motor neurons [170]. Studies on C9orf72 knockdown microglia also indicate several essential mechanisms underlying related motor neuron toxicity, including (i) elevated expression of complement component 3a receptor 1 (C3ar1) and complement component $1, Q$ subcomponent, $\beta$ polypeptide $(C 1 q b)$ in the activated C9orf72 knockdown microglia, enhancing synaptic pruning and related demand for endosomal/lysosomal integrity [70,171], (ii) elevated expression of tyrosine kinase binding protein (TYROBP) and triggering receptor expressed on myeloid cells 2 (TREM2) in the activated C9orf72 knockdown microglia, increasing microglial phagocytic 
activity [70], and (iii) a disturbed autophagy system in these microglia, causing p62 accumulation and enlarged lysosomes $[70,171]$. Altogether, these studies support the concept that C9orf72 haploinsufficiency may affect glial cell function through different mechanisms that ultimately lead to motor neuron toxicity (Figure 3).

\section{Biomarkers in C9orf72 ALS/FTD}

C9orf72 ALS/FTD is a complex disorder linked to numerous pathologic mechanisms. Current diagnostic measures are mainly based on clinical presentation and electrodiagnostic studies [172,173], which in most cases have limitations in early diagnosis of the disease where potential treatments could be most efficacious. This signifies the importance of finding specific biomarkers that could support an early diagnosis of C9orf72 ALS/FTD. Several studies have been conducted in recent years to identify diagnostic biomarkers for early diagnosis, disease progression, or to be used as indicators of therapeutic response in clinical trials in C9orf72 ALS/FTD.

\subsection{Non-Inflammatory Biomarkers}

One of the specific biomarkers in C9orf72 ALS/FTD that has caught attention in recent years is monitoring DPRs for tracking ALS in early diagnosis, natural history, and response to therapeutic intervention. Initial investigations created immunoassays for DPRs in tissue isolates (i.e., frontal/motor cortex, cerebellum, or hippocampus) from postmortem C9orf72 ALS/FTD cases [174]. Both poly-GP and poly-GA have higher expression in the CNS of C9orf72 ALS/FTD patients than poly-GR DPRs [175]. However, poly-GP is more likely to be correctly measured in biospecimens because it is more soluble than poly-GA [174]. Further studies have also detected poly-GP DPRs in the CSF $[76,176]$ and peripheral blood mononuclear cells [176] from C9orf72 ALS/FTD patients but not in healthy individuals or ALS patients who do not have the C9orf72 repeat expansion mutation. In a more recent multi-center prospective natural history study of 116 symptomatic C9orf72 ALS and 12 non-symptomatic C9orf72 repeat expansion carriers, it was revealed that the CSF concentrations of poly-GP DPRs remained high and steady over time in C9orf72 ALS patients [13]. Although there was a significant negative correlation between blood DNA repeat size and poly-GP CSF levels, no significant correlation was found between poly-GP CSF levels and ALS history measures (i.e., age at onset, survival, and ALSFRS-R rate of change) [13]. On the other hand, the stability of poly-GP levels over time may support the potential use of poly-GP as a pharmacodynamic biomarker. To investigate this, Gendron et al. (2017) evaluated the effects of a ribonuclease $\mathrm{H}$-active antisense oligonucleotide (ASO) that targets $\mathrm{G}_{4} \mathrm{C}_{2}$ repeat RNA on lymphoblastoid cell lines from C9orf72 ALS cases and in $\left(\mathrm{G}_{4} \mathrm{C}_{2}\right)_{66}$ mice, and an ASO that targets intron 1 of C9orf 72 on iPSC-derived neurons from C9orf72 ALS patients, and found that poly-GP levels were significantly decreased over time with treatment. This was concomitant with an improvement in C9orf 72 CNS pathology in mice, providing evidence that CSF poly-GP may serve as potential pharmacodynamic markers for treatments that target $\left(\mathrm{G}_{4} \mathrm{C}_{2}\right)_{\mathrm{n}}$ RNA [176].

The presence of nuclear RNA foci, which is another characteristic feature of C9orf 72 pathology, may be considered as another biomarker in C9orf72 ASL/FTD. These foci, which are visualized using RNA fluorescence in-situ hybridization (FISH) techniques [8,9], are detected in both brain cells and peripheral cells, including skin biopsy-derived fibroblasts [25,33,70], lymphoblasts [70], and peripheral blood leukocytes [69], making them a potential biomarker in disease progression and in clinical trials. The detection of RNA foci in muscle biopsy tissue using the RNA-FISH technique has been broadly employed as a diagnostic marker in myotonic dystrophy type 2 [177]. This test has not yet been investigated in the muscle biopsies of C9orf72 patients; instead, blood leukocytes may be utilized to determine whether therapies targeting C9orf72 repeat expansion will lower the number of RNA foci in leukocytes. 


\subsection{Inflammatory/Glial Biomarkers}

One of the common features of various neurodegenerative diseases including ALS is glial activation and elevated levels of inflammatory markers $[133,178]$. Unbiased proteomic analyses have interestingly discovered that complement activation and/or acute inflammatory responses are among the top pathways changed in the CSF of ALS patients compared to healthy individuals or other neurologic disorders $[179,180]$. Although detection of inflammatory mediators has been extensively investigated in ALS patients in general [181-183], little is known regarding their potential role as a biomarker specifically in C9orf72 ALS/FTD cases. For instance, reduced amounts of $\mathrm{C}-\mathrm{X}-\mathrm{C}$ motif chemokine ligand 10 protein (CXCL10), a microglial chemoattractant, are found in the CSF of C9orf72 ALS patients in comparison with other ALS cases [184]. In a recent study on FTD patients, out of the measured factors (monocyte chemoattractant protein-1 (MCP-1), regulated upon activation, normal T-cell expressed and secreted protein (RANTES), IL-10, IL-17A, IL-12p, IFN- $\gamma$, IL-8, IL-1 $\beta$, leukocytes, and C-reactive protein (CRP)), only serum IL-10 was different between C9orf72 FTD and non-C9orf72 FTD patients (carriers had higher levels), which negatively correlated to a more rapid disease progression [185]. Clearly, more investigations are needed to identify more specific inflammatory mediators as potential biomarkers in C9orf72 ALS/FTD.

MicroRNAs (miRNAs) are epigenetic modifiers of gene expression that act by binding argonaute 2 and forming the RNA-induced silencing complex [186]. Over 1000 miRNAs are present in humans. Alterations in miRNA expression and levels have been demonstrated in the CSF, serum, and plasma of patients with either sporadic or familial ALS [186-191]. However, there is scarce data regarding miRNAs that are specific for C9orf72 ALS/FTD pathology compared to healthy individuals or ALS/FTD patients without the C9orf72 repeat expansion mutation. For instance, Bengini et al. (2016) investigated the miRNA profiles of CSF from 24 ALS patients (including eight C9orf72 ALS cases) and 24 unaffected control subjects and identified eight miRNAs as significantly deregulated in ALS (especially upregulated miR181a-5p and downregulated miR21-5p and miR15b-5p, all of which are involved in apoptotic pathways) [187]. However, no significant differences were found between ALS patients with or without the C9orf72 repeat expansion mutation [187]. Another study also revealed that, while dysregulation of TDP-43 binding miRNAs (i.e., miR-143-5p/3p) may be a common feature of ALS pathology, downregulation of other TDP-43 binding miRNAs (i.e., miR-132-5p/3p and miR-574-5p/3p) was evident in sporadic, TARDBP, Fused In Sarcoma (FUS) and C9orf72, but not superoxide dismutase 1 (SOD1) mutant patients [190]. Downregulation of muscle-specific miR-206, involved in muscle re-innervation, in the SOD1 mutant mouse accelerated the disease progression and shortened survival [191]. If miRNAs specific for C9orf72 ALS/FTD patients are found and confirmed to be stable and secreted in the CSF (or even blood), these could be utilized as an invaluable readout for therapy efficacy. Notably, a recent study on the miRNA profile of extracellular vesicles secreted by C9orf 72 ALS astrocytes identified a unique set of 13 dysregulated miRNAs that contributed to axonal guidance and maintenance [165]. Among these, miR-494-3p was detected as the most dysregulated miRNA; its downregulation in the C9orf72 astrocytes-secreted extracellular vesicles was correlated with dramatic consequences on axonal/neurite length and motor neuron survival in vitro and in the postmortem ALS corticospinal tract [165]. Accordingly, treatment with a miR-494-3p mimic completely rescued neurite length and the number of nodes per cell, concurrent with a robust $20-25 \%$ increase in motor neuron survival [165]. Overall, it was found that downregulated miRNAs (i.e., miR-494-3p, miR-200c-3p, miR-668-3p, and miR-140-3p) target semaphorins, RhoA, and Rock, thus, predicting an elevation in these proteins, which could result in growth cone collapse. Upregulated miRNAs (i.e., miR-297, miR-595, miR-339-5p, miR-758-3P, and miR-449a) target ephrins and WW domain containing E3 ubiquitin protein ligase 1 (Wwp1), which would cause their downregulation. Wwp1 inactivates NogoA (also called reticulon 4); thus, this could also result in axonal collapse [165]. Therefore, these 
miRNAs, particularly miR-494-3p, might serve as potential inflammatory markers in future studies of C9orf72 ALS/FTD.

\subsection{Imaging-Based Markers}

Given the fact that non-invasive imaging techniques help monitor brain/spinal cord structures, neural networks, metabolism, and plasma membrane receptor distribution, they may serve as attractive markers for disease progression or treatment efficacy in ALS/FTD. Magnetic resonance imaging (MRI) and radionucleotide imaging (i.e., positron emission tomography (PET), single-photon emission computed tomography (SPECT)) are the two major techniques that have been recently investigated in this regard [192-194]. Consistent with previous histopathology studies on postmortem C9orf72 ALS cases $[14,195,196]$, recent results suggest a strong C9orf72-specific cortical and subcortical involvement reflecting more cognitive/behavioral deficits observed with this ALS genotype [197]. Several PET studies have also recently used radiotracers that bind to the $18 \mathrm{kD}$ translocator protein (TSPO), a protein that is highly expressed on activated microglia and astrocytes, to track gliosis in ALS patients [198]. Although, in general, these studies have demonstrated that the areas of increased uptake correlated positively with upper motor neuron burden scale and negatively with ALS functional rating scale-revised (ALSFRS-R) scores [199-201] (two patient-reported outcome measures), little is known about whether the degree of gliosis and such correlations are different between C9orf72 ALS/FTD and other ALS or healthy individuals. This warrants further detailed investigations.

\section{Therapeutic Approaches: Focus on Glial Cells}

Although there is still no definite cure for ALS, including C9orf72 ALS/FTD, progress in understanding the C9orf72 genetic architecture and its pathogenesis in ALS/FTD over the last decade has been inspiring and motivating. A better understanding of the mechanisms by which the C9orf 72 repeat expansion mutation exerts disease phenotypes has inspired multiple therapeutic approaches, providing hope for finding efficient therapies for this devastating disease in the near future. With the help of these translational approaches, several clinical trials for patients with ALS were initiated, including a phase I trial of ASOs targeting C9orf72 variants 1 and 3 RNA (BIIB078) (clinicaltrials.gov Identifier: NCT03626012) and a phase I trial of the nucleocytoplasmic transport inhibitor KPT-350 (also called BIIB100) [202] (clinicaltrials.gov identifier: NCT03945279). Despite accumulating evidence supporting a connection between C9orf72 ALS/FTD and neuroinflammation/autoimmunity, the fact that all trials using immunomodulatory or immunosuppressive medications (e.g., corticosteroids, cyclophosphamide, azathioprine, intravenous immunoglobulins, and plasmapheresis) have failed to show any efficacy in ALS patients [133] makes this area of research still challenging. Clearly, this issue warrants further study to understand the nature of the connection between the central inflammatory cells (i.e., glial cells) and motor neurons in the disease progress because glial cells can play both pro- and anti-inflammatory roles. Recent pre-clinical studies, for instance, have shown beneficial effects of certain C9orf72 ALS astrocyte-related miRNAs, such as miR-494-3p, on the survival of corticospinal motor neurons from C9orf72 ALS/FTD cases in vitro [165].

\section{Conclusions and Perspectives}

Since 2011 when the C9orf72 repeat expansion mutation was discovered as the most common genetic abnormality in familial ALS and FTD, an impressive number of studies have markedly improved our understanding of the pathologic mechanisms underlying the C9orf72 repeat expansion mutation. Although the normal function of C9orf72 in humans is yet to be fully understood, either loss of function/haploinsufficiency or toxic gain of function and related downstream pathways have been suggested as underlying mechanisms involved in the pathogenesis of C9orf72 ALS/FTD. Thus, therapies and biomarkers have been explored with respect to both mechanisms. One notable finding in recent studies is that there is an important role for glial cells in both loss- and gain-of-function theories. Here, 
we discussed the current literature showing pathologic roles of microglia and astrocytes in C9orf72 ALS/FTD, including accumulating evidence of gliosis in C9orf72 ALS/FTD, pathologic hallmarks in glial cells such as TDP-43 and p62 aggregates, and toxicity of C9orf72 glial cells. Despite tremendous efforts on the study of glial cells in C9orf72 ALS/FTD during the last several years, there are still several challenging issues. One important issue is that to what extent both loss- and gain-of-function theories play a concomitant role in glial cells' involvement in C9orf72 ALS/FTD. Data from immune system dysregulation have mainly emerged from the studies on C9orf72 deficient animals. Although C9orf72-/mice exhibit severe dysregulation of the immune system and autoimmune phenotypes, more studies are clearly needed to assess a link between peripheral immune cells and CNS residual cells in disease development or progress. Concomitant modeling of loss- and gain-of-function pathways can also shed more light on the roles of microglia and astrocytes in the disease pathogenesis.

Another important issue is the cross talk between glial cells and neurons. Although limited data indicate that glial activation and neuroinflammation may precede neurodegeneration in C9orf72 ASL/FTD, it is still elusive what factors contribute to this phenomenon, especially given the fact that pathologic C9orf72 hallmarks of DPRs and RNA foci are less observed in glial cells than neurons, which makes the condition more challenging. Although there are several hypotheses in this regard (including less expression of the C9orf72 repeated expansion mutation, less expression of RNA binding proteins involved in RNA aggregates, better clearance of C9orf72 repeated expansion containing RNA, less cytosolic translocation of C9orf72 repeated expansion containing RNA, less RAN translation, enhanced degradation of DPRs prior to their accumulation, or finally, the transference of DPRs from neurons to glial cells through possible cell-to-cell communication between neurons and glia), more studies are warranted to clearly understand this issue and test these hypotheses.

A better understanding of the underlying signaling pathways related to the aberrant function of glia in C9orf72 ALS/FTD can provide new insights into both appropriate glial markers for disease monitoring and therapeutic approaches to slow disease progression. Thus, more studies are needed to further elucidate the roles of microglia and astrocytes in C9orf72 ALS/FTD pathogenesis.

Author Contributions: Conceptualization and design, M.G.; original draft preparation, M.G. and K.K.; critical edition, C.D.; final edition and revision of manuscript, M.G., K.K., and C.D. All authors have read and agreed to the published version of the manuscript.

Funding: M.G. is supported by a clinical research training scholarship in ALS funded by the ALS Association and the American Brain Foundation, in collaboration with the American Academy of Neurology.

Institutional Review Board Statement: Not applicable.

Informed Consent Statement: Not applicable.

Data Availability Statement: Not applicable.

Acknowledgments: Figure 4 was created with BioRender.com.

Conflicts of Interest: The authors declare no conflict of interest.

\section{References}

1. Zucchi, E.; Ticozzi, N.; Mandrioli, J. Psychiatric Symptoms in Amyotrophic Lateral Sclerosis: Beyond a Motor Neuron Disorder. Front. Neurosci. 2019, 13, 175. [CrossRef]

2. Ghasemi, M.; Brown, R.H., Jr. Genetics of Amyotrophic Lateral Sclerosis. Cold Spring Harb. Perspect. Med. 2018, 8, a024125. [CrossRef] [PubMed]

3. Al-Sarraj, S.; King, A.; Troakes, C.; Smith, B.; Maekawa, S.; Bodi, I.; Rogelj, B.; Al-Chalabi, A.; Hortobágyi, T.; Shaw, C.E. p62 positive, TDP-43 negative, neuronal cytoplasmic and intranuclear inclusions in the cerebellum and hippocampus define the pathology of C9orf72-linked FTLD and MND/ALS. Acta Neuropathol. 2011, 122, 691-702. [CrossRef] [PubMed] 
4. Cooper-Knock, J.; Hewitt, C.; Highley, J.R.; Brockington, A.; Milano, A.; Man, S.; Martindale, J.; Hartley, J.; Walsh, T.; Gelsthorpe, C.; et al. Clinico-pathological features in amyotrophic lateral sclerosis with expansions in C9ORF72. Brain 2012, 135, 751-764. [CrossRef] [PubMed]

5. Schipper, L.J.; Raaphorst, J.; Aronica, E.; Baas, F.; De Haan, R.J.; De Visser, M.; Troost, D. Prevalence of brain and spinal cord inclusions, including dipeptide repeat proteins, in patients with the C9ORF72 hexanucleotide repeat expansion: A systematic neuropathological review. Neuropathol. Appl. Neurobiol. 2016, 42, 547-560. [CrossRef] [PubMed]

6. Simón-Sánchez, J.; Dopper, E.G.P.; Cohn-Hokke, P.E.; Hukema, R.K.; Nicolaou, N.; Seelaar, H.; De Graaf, J.R.A.; De Koning, I.; Van Schoor, N.M.; Deeg, D.J.H.; et al. The clinical and pathological phenotype of C9ORF72 hexanucleotide repeat expansions. Brain 2012, 135, 723-735. [CrossRef] [PubMed]

7. Jiang, J.; Ravits, J.M. Pathogenic Mechanisms and Therapy Development for C9orf72 Amyotrophic Lateral Sclerosis/Frontotemporal Dementia. Neurotherapeutics 2019, 16, 1115-1132. [CrossRef] [PubMed]

8. DeJesus-Hernandez, M.; MacKenzie, I.R.; Boeve, B.F.; Boxer, A.L.; Baker, M.; Rutherford, N.J.; Nicholson, A.M.; Finch, N.A.; Flynn, H.; Adamson, J.; et al. Expanded GGGGCC Hexanucleotide Repeat in Noncoding Region of C9ORF72 Causes Chromosome 9p-Linked FTD and ALS. Neuron 2011, 72, 245-256. [CrossRef]

9. Renton, A.E.; Majounie, E.; Waite, A.; Simón-Sánchez, J.; Rollinson, S.; Gibbs, J.R.; Schymick, J.C.; Laaksovirta, H.; Van Swieten, J.C.; Myllykangas, L.; et al. A Hexanucleotide Repeat Expansion in C9ORF72 Is the Cause of Chromosome 9p21-Linked ALS-FTD. Neuron 2011, 72, 257-268. [CrossRef]

10. Gijselinck, I.; Van Langenhove, T.; Van Der Zee, J.; Sleegers, K.; Philtjens, S.; Kleinberger, G.; Janssens, J.; Bettens, K.; Van Cauwenberghe, C.; Pereson, S.; et al. A C9orf72 promoter repeat expansion in a Flanders-Belgian cohort with disorders of the frontotemporal lobar degeneration-amyotrophic lateral sclerosis spectrum: A gene identification study. Lancet Neurol. 2012, 11, 54-65. [CrossRef]

11. Nguyen, H.P.; Van Broeckhoven, C.; Van Der Zee, J. ALS Genes in the Genomic Era and their Implications for FTD. Trends Genet. 2018, 34, 404-423. [CrossRef] [PubMed]

12. Haeusler, A.R.; Donnelly, C.J.; Rothstein, J.D. The expanding biology of the C9orf72 nucleotide repeat expansion in neurodegenerative disease. Nat. Rev. Neurosci. 2016, 17, 383-395. [CrossRef] [PubMed]

13. Cammack, A.J.; Atassi, N.; Hyman, T.; Van Den Berg, L.H.; Harms, M.; Baloh, R.H.; Brown, R.H.; Van Es, M.A.; Veldink, J.H.; De Vries, B.S.; et al. Prospective natural history study of C9orf72 ALS clinical characteristics and biomarkers. Neurology 2019, 93, e1605-e1617. [CrossRef] [PubMed]

14. Byrne, S.C.; Elamin, M.; Bede, P.; Shatunov, A.; Walsh, C.; Corr, B.; Heverin, M.; Jordan, N.; Kenna, K.; Lynch, C.; et al. Cognitive and clinical characteristics of patients with amyotrophic lateral sclerosis carrying a C9orf72 repeat expansion: A population-based cohort study. Lancet Neurol. 2012, 11, 232-240. [CrossRef]

15. Millecamps, S.; Boillée, S.; Le Ber, I.; Seilhean, D.; Teyssou, E.; Giraudeau, M.; Moigneu, C.; Vandenberghe, N.; Danel-Brunaud, V.; Corcia, P.; et al. Phenotype difference between ALS patients with expanded repeats in C9ORF72 and patients with mutations in other ALS-related genes. J. Med. Genet. 2012, 49, 258-263. [CrossRef]

16. Chiò, A.; Borghero, G.; Restagno, G.; Mora, G.; Drepper, C.; Traynor, B.J.; Sendtner, M.; Brunetti, M.; Ossola, I.; Calvo, A.; et al. Clinical characteristics of patients with familial amyotrophic lateral sclerosis carrying the pathogenic GGGGCC hexanucleotide repeat expansion of C9ORF72. Brain 2012, 135, 784-793. [CrossRef]

17. Irwin, D.J.; McMillan, C.T.; Brettschneider, J.; Libon, D.J.; Powers, J.; Rascovsky, K.; Toledo, J.B.; Boller, A.; Bekisz, J.; Chandrasekaran, K.; et al. Cognitive decline and reduced survival in C9orf72 expansion frontotemporal degeneration and amyotrophic lateral sclerosis. J. Neurol. Neurosurg. Psychiatry 2013, 84, 163-169. [CrossRef]

18. Snowden, J.S.; Adams, J.; Harris, J.; Thompson, J.C.; Rollinson, S.; Richardson, A.; Jones, M.J.; Neary, D.; Mann, D.M.; PickeringBrown, S. Distinct clinical and pathological phenotypes in frontotemporal dementia associated with MAPT, PGRN and C9orf72 mutations. Amyotroph. Lateral Scler. Front. Degener. 2015, 16, 497-505. [CrossRef]

19. Picher-Martel, V.; Valdmanis, P.N.; Gould, P.V.; Julien, J.-P.; Dupre, N. From animal models to human disease: A genetic approach for personalized medicine in ALS. Acta Neuropathol. Commun. 2016, 4, 1-29. [CrossRef]

20. Ciura, S.; Lattante, S.; Le Ber, I.; Latouche, M.; Tostivint, H.; Brice, A.; Kabashi, E. Loss of function of C9orf72 causes motor deficits in a zebrafish model of Amyotrophic Lateral Sclerosis. Ann. Neurol. 2013, 74, 180-187. [CrossRef]

21. Fratta, P.; Poulter, M.; Lashley, T.; Rohrer, J.D.; Polke, J.M.; Beck, J.; Ryan, N.; Hensman, D.; Mizielinska, S.; Waite, A.J.; et al. Homozygosity for the C9orf72 GGGGCC repeat expansion in frontotemporal dementia. Acta Neuropathol. 2013, 126, 401-409. [CrossRef] [PubMed]

22. Belzil, V.V.; Bauer, P.O.; Prudencio, M.; Gendron, T.F.; Stetler, C.T.; Yan, I.K.; Pregent, L.; Daughrity, L.; Baker, M.C.; Rademakers, R.; et al. Reduced C9orf72 gene expression in c9FTD/ALS is caused by histone trimethylation, an epigenetic event detectable in blood. Acta Neuropathol. 2013, 126, 895-905. [CrossRef] [PubMed]

23. Waite, A.J.; Bäumer, D.; East, S.; Neal, J.; Morris, H.R.; Ansorge, O.; Blake, D.J. Reduced C9orf72 protein levels in frontal cortex of amyotrophic lateral sclerosis and frontotemporal degeneration brain with the C9ORF72 hexanucleotide repeat expansion. Neurobiol. Aging 2014, 35, 1779.e5-1779.e13. [CrossRef] [PubMed]

24. Van Blitterswijk, M.; Gendron, T.F.; Baker, M.C.; DeJesus-Hernandez, M.; Finch, N.A.; Brown, P.H.; Daughrity, L.M.; Murray, M.E.; Heckman, M.G.; Jiang, J.; et al. Novel clinical associations with specific C9ORF72 transcripts in patients with repeat expansions in C9ORF72. Acta Neuropathol. 2015, 130, 863-876. [CrossRef] [PubMed] 
25. Donnelly, C.J.; Zhang, P.-W.; Pham, J.T.; Haeusler, A.R.; Mistry, N.A.; Vidensky, S.; Daley, E.L.; Poth, E.M.; Hoover, B.; Fines, D.M.; et al. RNA Toxicity from the ALS/FTD C9ORF72 Expansion Is Mitigated by Antisense Intervention. Neuron 2013, 80, 415-428. [CrossRef] [PubMed]

26. Peters, O.M.; Ghasemi, M.; Brown, R.H., Jr. Emerging mechanisms of molecular pathology in ALS. J. Clin. Investig. 2015, 125, 1767-1779. [CrossRef]

27. Tran, H.; Almeida, S.; Moore, J.M.; Gendron, T.F.; Chalasani, U.; Lu, Y.; Du, X.; Nickerson, J.A.; Petrucelli, L.; Weng, Z.; et al. Differential Toxicity of Nuclear RNA Foci versus Dipeptide Repeat Proteins in a Drosophila Model of C9ORF72 FTD/ALS. Neuron 2015, 87, 1207-1214. [CrossRef]

28. Rizzu, P.; Blauwendraat, C.; Heetveld, S.; Lynes, E.M.; Castillo-Lizardo, M.; Dhingra, A.; Pyz, E.; Hobert, M.; Synofzik, M.; Simón-Sánchez, J.; et al. C9orf72 is differentially expressed in the central nervous system and myeloid cells and consistently reduced in C9orf72, MAPT and GRN mutation carriers. Acta Neuropathol. Commun. 2016, 4, 37. [CrossRef]

29. Frick, P.; Sellier, C.; MacKenzie, I.R.A.; Cheng, C.-Y.; Tahraoui-Bories, J.; Martinat, C.; Pasterkamp, R.J.; Prudlo, J.; Edbauer, D.; Oulad-Abdelghani, M.; et al. Novel antibodies reveal presynaptic localization of C9orf72 protein and reduced protein levels in C9orf72 mutation carriers. Acta Neuropathol. Commun. 2018, 6, 72. [CrossRef]

30. Xiao, S.; Macnair, L.; McGoldrick, P.; McKeever, P.M.; McLean, J.R.; Zhang, M.; Keith, J.; Zinman, L.; Rogaeva, E.; Robertson, J. Isoform-specific antibodies reveal distinct subcellular localizations of C9orf72 in amyotrophic lateral sclerosis. Ann. Neurol. 2015, 78, 568-583. [CrossRef]

31. Atkinson, R.; Fernandez-Martos, C.M.; Atkin, J.D.; Vickers, J.C.; King, A.E. C9ORF72 expression and cellular localization over mouse development. Acta Neuropathol. Commun. 2015, 3, 59. [CrossRef] [PubMed]

32. Mori, K.; Weng, S.-M.; Arzberger, T.; May, S.; Rentzsch, K.; Kremmer, E.; Schmid, B.; Kretzschmar, H.A.; Cruts, M.; Van Broeckhoven, C.; et al. The C9orf72 GGGGCC Repeat Is Translated into Aggregating Dipeptide-Repeat Proteins in FTLD/ALS. Science 2013, 339, 1335-1338. [CrossRef] [PubMed]

33. Almeida, S.; Gascon, E.; Tran, H.; Chou, H.J.; Gendron, T.F.; DeGroot, S.; Tapper, A.R.; Sellier, C.; Charlet-Berguerand, N.; Karydas, A.; et al. Modeling key pathological features of frontotemporal dementia with C9ORF72 repeat expansion in iPSC-derived human neurons. Acta Neuropathol. 2013, 126, 385-399. [CrossRef] [PubMed]

34. Shi, Y.; Lin, S.; Staats, K.A.; Li, Y.; Chang, W.-H.; Hung, S.-T.; Hendricks, E.; Linares, G.R.; Wang, Y.; Son, E.Y.; et al. Haploinsufficiency leads to neurodegeneration in C9ORF72 ALS/FTD human induced motor neurons. Nat. Med. 2018, $24,313-325$. [CrossRef] [PubMed]

35. Xi, Z.; Zinman, L.; Moreno, D.; Schymick, J.; Liang, Y.; Sato, C.; Zheng, Y.; Ghani, M.; Dib, S.; Keith, J.; et al. Hypermethylation of the CpG Island Near the G4C2 Repeat in ALS with a C9orf72 Expansion. Am. J. Hum. Genet. 2013, 92, 981-989. [CrossRef] [PubMed]

36. Zhang, D.; Iyer, L.M.; He, F.; Aravind, L. Discovery of Novel DENN Proteins: Implications for the Evolution of Eukaryotic Intracellular Membrane Structures and Human Disease. Front. Genet. 2012, 3, 283. [CrossRef]

37. Webster, C.P.; Smith, E.F.; Bauer, C.S.; Moller, A.; Hautbergue, G.M.; Ferraiuolo, L.; Myszczynska, M.A.; Higginbottom, A.; Walsh, M.J.; Whitworth, A.J.; et al. The C9orf72 protein interacts with Rab1a and the ULK 1 complex to regulate initiation of autophagy. EMBO J. 2016, 35, 1656-1676. [CrossRef]

38. Webster, C.P.; Smith, E.F.; Grierson, A.J.; De Vos, K.J. C9orf72 plays a central role in Rab GTPase-dependent regulation of autophagy. Small GTPases 2018, 9, 399-408. [CrossRef]

39. Iyer, S.; Subramanian, V.; Acharya, K.R. C9orf72, a protein associated with amyotrophic lateral sclerosis (ALS) is a guanine nucleotide exchange factor. PeerJ 2018, 6, e5815. [CrossRef]

40. Farg, M.A.; Sundaramoorthy, V.; Sultana, J.M.; Yang, S.; Atkinson, R.A.; Levina, V.; Halloran, M.A.; Gleeson, P.A.; Blair, I.P.; Soo, K.Y.; et al. C9ORF72, implicated in amytrophic lateral sclerosis and frontotemporal dementia, regulates endosomal trafficking. Hum. Mol. Genet. 2014, 23, 3579-3595. [CrossRef]

41. Elden, A.C.; Kim, H.-J.; Hart, M.P.; Chen-Plotkin, A.S.; Johnson, B.S.; Fang, X.; Armakola, M.; Geser, F.; Greene, R.; Lu, M.M.; et al. Ataxin-2 intermediate-length polyglutamine expansions are associated with increased risk for ALS. Nature 2010, 466, 1069-1075. [CrossRef] [PubMed]

42. Daoud, H.; Belzil, V.; Martins, S.; Sabbagh, M.; Provencher, P.; Lacomblez, L.; Meininger, V.; Camu, W.; Dupré, N.; Dion, P.A.; et al. Association of Long ATXN2 CAG Repeat Sizes with Increased Risk of Amyotrophic Lateral Sclerosis. Arch. Neurol. 2011, 68, 739-742. [CrossRef] [PubMed]

43. Ross, O.A.; Rutherford, N.J.; Baker, M.; Soto-Ortolaza, A.I.; Carrasquillo, M.M.; DeJesus-Hernandez, M.; Adamson, J.; Li, M.; Volkening, K.; Finger, E.; et al. Ataxin-2 repeat-length variation and neurodegeneration. Hum. Mol. Genet. 2011, 20, $3207-3212$. [CrossRef] [PubMed]

44. Lattante, S.; Millecamps, S.; Stevanin, G.; Rivaud-Péchoux, S.; Moigneu, C.; Camuzat, A.; Da Barroca, S.; Mundwiller, E.; Couarch, P.; Salachas, F.; et al. Contribution of ATXN2 intermediary polyQ expansions in a spectrum of neurodegenerative disorders. Neurology 2014, 83, 990-995. [CrossRef] [PubMed]

45. Sellier, C.; Campanari, M.-L.; Corbier, C.J.; Gaucherot, A.; Kolb-Cheynel, I.; Oulad-Abdelghani, M.; Ruffenach, F.; Page, A.; Ciura, S.; Kabashi, E.; et al. Loss of C9ORF72 impairs autophagy and synergizes with polyQ Ataxin-2 to induce motor neuron dysfunction and cell death. EMBO J. 2016, 35, 1276-1297. [CrossRef] [PubMed] 
46. Sudria-Lopez, E.; Koppers, M.; De Wit, M.; Van Der Meer, C.; Westeneng, H.-J.; Zundel, C.A.C.; Youssef, S.A.; Harkema, L.; De Bruin, A.; Veldink, J.H.; et al. Full ablation of C9orf72 in mice causes immune system-related pathology and neoplastic events but no motor neuron defects. Acta Neuropathol. 2016, 132, 145-147. [CrossRef]

47. Aoki, Y.; Manzano, R.; Lee, Y.; Dafinca, R.; Aoki, M.; Douglas, A.G.L.; Varela, M.A.; Sathyaprakash, C.; Scaber, J.; Barbagallo, P.; et al. C9orf72 and RAB7L1 regulate vesicle trafficking in amyotrophic lateral sclerosis and frontotemporal dementia. Brain 2017, 140, 887-897. [CrossRef]

48. Amick, J.; Roczniak-Ferguson, A.; Ferguson, S.M. C9orf72 binds SMCR8, localizes to lysosomes, and regulates mTORC1 signaling. Mol. Biol. Cell 2016, 27, 3040-3051. [CrossRef]

49. Burk, K.; Pasterkamp, R.J. Disrupted neuronal trafficking in amyotrophic lateral sclerosis. Acta Neuropathol. 2019, 137, 859-877. [CrossRef]

50. Huber, L.A.; Pimplikar, S.; Parton, R.G.; Virta, H.; Zerial, M.; Simons, K. Rab8, a small GTPase involved in vesicular traffic between the TGN and the basolateral plasma membrane. J. Cell Biol. 1993, 123, 35-45. [CrossRef]

51. King, A.E.; Woodhouse, A.; Kirkcaldie, M.T.; Vickers, J.C. Excitotoxicity in ALS: Overstimulation, or overreaction? Exp. Neurol. 2016, 275 Pt 1, 162-171. [CrossRef]

52. Bursch, F.; Kalmbach, N.; Naujock, M.; Staege, S.; Eggenschwiler, R.; Abo-Rady, M.; Japtok, J.; Guo, W.; Hensel, N.; Reinhardt, P.; et al. Altered calcium dynamics and glutamate receptor properties in iPSC derived motor neurons from ALS patients with C9orf72, FUS, SOD1 or TDP43 mutations. Hum. Mol. Genet. 2019, 28, 2835-2850. [CrossRef] [PubMed]

53. Selvaraj, B.T.; Livesey, M.R.; Zhao, C.; Gregory, J.M.; James, O.T.; Cleary, E.M.; Chouhan, A.K.; Gane, A.B.; Perkins, E.M.; Dando, O.; et al. C9ORF72 repeat expansion causes vulnerability of motor neurons to $\mathrm{Ca}^{2+}$-permeable AMPA receptor-mediated excitotoxicity. Nat. Commun. 2018, 9, 347. [CrossRef] [PubMed]

54. Moore, S.; Alsop, E.; Lorenzini, I.; Starr, A.; Rabichow, B.E.; Mendez, E.; Levy, J.L.; Burciu, C.; Reiman, R.; Chew, J.; et al. ADAR2 mislocalization and widespread RNA editing aberrations in C9orf72-mediated ALS/FTD. Acta Neuropathol. 2019, $138,49-65$. [CrossRef]

55. Hideyama, T.; Yamashita, T.; Suzuki, T.; Tsuji, S.; Higuchi, M.; Seeburg, P.H.; Takahashi, R.; Misawa, H.; Kwak, S. Induced Loss of ADAR2 Engenders Slow Death of Motor Neurons from Q/R Site-Unedited GluR2. J. Neurosci. 2010, 30, 11917-11925. [CrossRef] [PubMed]

56. Shi, Y.; Hung, S.-T.; Rocha, G.; Lin, S.; Linares, G.R.; Staats, K.A.; Seah, C.; Wang, Y.; Chickering, M.; Lai, J.; et al. Identification and therapeutic rescue of autophagosome and glutamate receptor defects in C9ORF72 and sporadic ALS neurons. JCI Insight 2019, 4. [CrossRef]

57. Koppers, M.; Blokhuis, A.M.; Westeneng, H.; Terpstra, M.L.; Zundel, C.A.C.; De Sá, R.V.; Schellevis, R.D.; Waite, A.J.; Blake, D.J.; Veldink, J.H.; et al. C 9orf72 ablation in mice does not cause motor neuron degeneration or motor deficits. Ann. Neurol. 2015, 78, 426-438. [CrossRef]

58. Jiang, J.; Zhu, Q.; Gendron, T.F.; Saberi, S.; McAlonis-Downes, M.; Seelman, A.; Stauffer, J.E.; Jafar-Nejad, P.; Drenner, K.; Schulte, D.; et al. Gain of Toxicity from ALS/FTD-Linked Repeat Expansions in C9ORF72 Is Alleviated by Antisense Oligonucleotides Targeting GGGGCC-Containing RNAs. Neuron 2016, 90, 535-550. [CrossRef]

59. Atanasio, A.; Decman, V.; White, D.; Ramos, M.; Ikiz, B.; Lee, H.-C.; Siao, C.-J.; Brydges, S.; LaRosa, E.; Bai, Y.; et al. C9orf72 ablation causes immune dysregulation characterized by leukocyte expansion, autoantibody production and glomerulonephropathy in mice. Sci. Rep. 2016, 6, 23204. [CrossRef]

60. O'Rourke, J.G.; Bogdanik, L.; Yáñez, A.; Lall, D.; Wolf, A.J.; Muhammad, A.K.M.G.; Ho, R.; Carmona, S.; Vit, J.P.; Zarrow, J.; et al. C9orf72 is required for proper macrophage and microglial function in mice. Science 2016, 351, 1324-1329. [CrossRef]

61. Burberry, A.; Suzuki, N.; Wang, J.-Y.; Moccia, R.; Mordes, D.A.; Stewart, M.H.; Suzuki-Uematsu, S.; Ghosh, S.; Singh, A.; Merkle, F.T.; et al. Loss-of-function mutations in the C9ORF72 mouse ortholog cause fatal autoimmune disease. Sci. Transl. Med. 2016, 8, 347ra93. [CrossRef] [PubMed]

62. Ugolino, J.; Ji, Y.J.; Conchina, K.; Chu, J.; Nirujogi, R.S.; Pandey, A.; Brady, N.R.; Hamacher-Brady, A.; Wang, J. Loss of C9orf72 Enhances Autophagic Activity via Deregulated mTOR and TFEB Signaling. PLoS Genet. 2016, 12, e1006443. [CrossRef] [PubMed]

63. Sullivan, P.M.; Zhou, X.; Robins, A.M.; Paushter, D.H.; Kim, D.; Smolka, M.B.; Hu, F. The ALS/FTLD associated protein C9orf72 associates with SMCR8 and WDR41 to regulate the autophagy-lysosome pathway. Acta Neuropathol. Commun. $2016,4,51$. [CrossRef] [PubMed]

64. Balendra, R.; Isaacs, A.M. C9orf72-mediated ALS and FTD: Multiple pathways to disease. Nat. Rev. Neurol. 2018, 14, 544-558. [CrossRef] [PubMed]

65. Robberecht, W.; Philips, T. The changing scene of amyotrophic lateral sclerosis. Nat. Rev. Neurosci. 2013, 14, 248-264. [CrossRef]

66. Chew, J.; Gendron, T.F.; Prudencio, M.; Sasaguri, H.; Zhang, Y.-J.; Castanedes-Casey, M.; Lee, C.W.; Jansen-West, K.; Kurti, A.; Murray, M.E.; et al. C9ORF72 repeat expansions in mice cause TDP-43 pathology, neuronal loss, and behavioral deficits. Science 2015, 348, 1151-1154. [CrossRef]

67. Gendron, T.F.; Bieniek, K.F.; Zhang, Y.-J.; Jansen-West, K.; Ash, P.E.A.; Caulfield, T.; Daughrity, L.; Dunmore, J.H.; CastanedesCasey, M.; Chew, J.; et al. Antisense transcripts of the expanded C9ORF72 hexanucleotide repeat form nuclear RNA foci and undergo repeat-associated non-ATG translation in c9FTD/ALS. Acta Neuropathol. 2013, 126, 829-844. [CrossRef] 
68. Mori, K.; Arzberger, T.; Grässer, F.A.; Gijselinck, I.; May, S.; Rentzsch, K.; Weng, S.-M.; Schludi, M.H.; Van Der Zee, J.; Cruts, M.; et al. Bidirectional transcripts of the expanded C9orf72 hexanucleotide repeat are translated into aggregating dipeptide repeat proteins. Acta Neuropathol. 2013, 126, 881-893. [CrossRef]

69. Zu, T.; Liu, Y.; Bañez-Coronel, M.; Reid, T.; Pletnikova, O.; Lewis, J.; Miller, T.M.; Harms, M.B.; Falchook, A.E.; Subramony, S.H.; et al. RAN proteins and RNA foci from antisense transcripts in C9ORF72 ALS and frontotemporal dementia. Proc. Natl. Acad. Sci. USA 2013, 110, E4968-E4977. [CrossRef]

70. Lagier-Tourenne, C.; Baughn, M.; Rigo, F.; Sun, S.; Liu, P.; Li, H.-R.; Jiang, J.; Watt, A.T.; Chun, S.; Katz, M.; et al. Targeted degradation of sense and antisense C9orf72 RNA foci as therapy for ALS and frontotemporal degeneration. Proc. Natl. Acad. Sci. USA 2013, 110, E4530-E4539. [CrossRef]

71. Sareen, D.; O’Rourke, J.G.; Meera, P.; Muhammad, A.K.M.G.; Grant, S.; Simpkinson, M.; Bell, S.; Carmona, S.; Ornelas, L.; Sahabian, A.; et al. Targeting RNA Foci in iPSC-Derived Motor Neurons from ALS Patients with a C9ORF72 Repeat Expansion. Sci. Transl. Med. 2013, 5, 208ra149. [CrossRef] [PubMed]

72. La Spada, A.R.; Taylor, J.P. Repeat expansion disease: Progress and puzzles in disease pathogenesis. Nat. Rev. Genet. 2010, 11, 247-258. [CrossRef] [PubMed]

73. Fratta, P.; Mizielinska, S.; Nicoll, A.J.; Zloh, M.; Fisher, E.M.C.; Parkinson, G.N.; Isaacs, A.M. C9orf72 hexanucleotide repeat associated with amyotrophic lateral sclerosis and frontotemporal dementia forms RNA G-quadruplexes. Sci. Rep. 2012, 2, srep01016. [CrossRef] [PubMed]

74. Wang, X.; Goodrich, K.J.; Conlon, E.G.; Gao, J.; Erbse, A.H.; Manley, J.L.; Cech, T.R. C9orf72 and triplet repeat disorder RNAs: G-quadruplex formation, binding to PRC2 and implications for disease mechanisms. RNA 2019, 25, 935-947. [CrossRef]

75. Taylor, J.P. Neurodegenerative diseases: G-quadruplex poses quadruple threat. Nature 2014, 507, 175-177. [CrossRef]

76. Su, Z.; Zhang, Y.; Gendron, T.F.; Bauer, P.O.; Chew, J.; Yang, W.-Y.; Fostvedt, E.; Jansen-West, K.; Belzil, V.V.; Desaro, P.; et al. Discovery of a Biomarker and Lead Small Molecules to Target r(GGGGCC)-Associated Defects in c9FTD/ALS. Neuron 2014, 83, 1043-1050. [CrossRef]

77. Haeusler, A.R.; Donnelly, C.J.; Periz, G.; Simko, E.A.J.; Shaw, P.G.; Kim, M.-S.; Maragakis, N.J.; Troncoso, J.C.; Pandey, A.; Sattler, R.; et al. C9orf72 nucleotide repeat structures initiate molecular cascades of disease. Nature 2014, 507, 195-200. [CrossRef]

78. Reddy, K.; Zamiri, B.; Stanley, S.Y.R.; MacGregor, R.B.; Pearson, C.E. The Disease-associated r(GGGGCC) Repeat from the C9orf72 Gene Forms Tract Length-dependent Uni- and Multimolecular RNA G-quadruplex Structures. J. Biol. Chem. 2013, 288, 9860-9866. [CrossRef]

79. Zhou, B.; Geng, Y.; Liu, C.; Miao, H.; Ren, Y.; Xu, N.; Shi, X.; You, Y.; Lee, T.; Zhu, G. Characterizations of distinct parallel and antiparallel G-quadruplexes formed by two-repeat ALS and FTD related GGGGCC sequence. Sci. Rep. 2018, 8, 2366. [CrossRef]

80. Brčić, J.; Plavec, J. NMR structure of a G-quadruplex formed by four d(G4C2) repeats: Insights into structural polymorphism. Nucleic Acids Res. 2018, 46, 11605-11617. [CrossRef]

81. Skourti-Stathaki, K.; Proudfoot, N.J.; Gromak, N. Human Senataxin Resolves RNA/DNA Hybrids Formed at Transcriptional Pause Sites to Promote Xrn2-Dependent Termination. Mol. Cell 2011, 42, 794-805. [CrossRef] [PubMed]

82. Yüce, Ö.; West, S.C. Senataxin, Defective in the Neurodegenerative Disorder Ataxia with Oculomotor Apraxia 2, Lies at the Interface of Transcription and the DNA Damage Response. Mol. Cell. Biol. 2012, 33, 406-417. [CrossRef] [PubMed]

83. Vatovec, S.; Kovanda, A.; Rogelj, B. Unconventional features of C9ORF72 expanded repeat in amyotrophic lateral sclerosis and frontotemporal lobar degeneration. Neurobiol. Aging 2014, 35, 2421.e1-2421.e12. [CrossRef] [PubMed]

84. Kovanda, A.; Zalar, M.; Šket, P.; Plavec, J.; Rogelj, B. Anti-sense DNA d(GGCCCC)n expansions in C9ORF72 form i-motifs and protonated hairpins. Sci. Rep. 2015, 5, 17944. [CrossRef]

85. Zhang, Y.; Roland, C.; Sagui, C. Structure and Dynamics of DNA and RNA Double Helices Obtained from the GGGGCC and CCCCGG Hexanucleotide Repeats That Are the Hallmark of C9FTD/ALS Diseases. ACS Chem. Neurosci. 2017, 8, 578-591. [CrossRef] [PubMed]

86. Ash, P.E.; Bieniek, K.F.; Gendron, T.F.; Caulfield, T.; Lin, W.-L.; DeJesus-Hernandez, M.; Van Blitterswijk, M.M.; Jansen-West, K.; Paul, J.W., III; Rademakers, R.; et al. Unconventional Translation of C9ORF72 GGGGCC Expansion Generates Insoluble Polypeptides Specific to c9FTD/ALS. Neuron 2013, 77, 639-646. [CrossRef]

87. Wen, X.; Tan, W.; Westergard, T.; Krishnamurthy, K.; Markandaiah, S.S.; Shi, Y.; Lin, S.; Shneider, N.A.; Monaghan, J.; Pandey, U.B.; et al. Antisense Proline-Arginine RAN Dipeptides Linked to C9ORF72-ALS/FTD Form Toxic Nuclear Aggregates that Initiate In Vitro and In Vivo Neuronal Death. Neuron 2014, 84, 1213-1225. [CrossRef]

88. Tao, Z.; Wang, H.; Xia, Q.; Li, K.; Li, K.; Jiang, X.; Xu, G.; Wang, G.; Ying, Z. Nucleolar stress and impaired stress granule formation contribute to C9orf72 RAN translation-induced cytotoxicity. Hum. Mol. Genet. 2015, 24, 2426-2441. [CrossRef]

89. Kanekura, K.; Yagi, T.; Cammack, A.J.; Mahadevan, J.; Kuroda, M.; Harms, M.B.; Miller, T.M.; Urano, F. Poly-dipeptides encoded by the C9ORF72 repeats block global protein translation. Hum. Mol. Genet. 2016, 25, 1803-1813. [CrossRef]

90. Zhang, Y.-J.; Jansen-West, K.; Xu, Y.-F.; Gendron, T.F.; Bieniek, K.F.; Lin, W.-L.; Sasaguri, H.; Caulfield, T.; Hubbard, J.; Daughrity, L.; et al. Aggregation-prone c9FTD/ALS poly(GA) RAN-translated proteins cause neurotoxicity by inducing ER stress. Acta Neuropathol. 2014, 128, 505-524. [CrossRef]

91. May, S.; Hornburg, D.; Schludi, M.H.; Arzberger, T.; Rentzsch, K.; Schwenk, B.M.; Grässer, F.A.; Mori, K.; Kremmer, E.; BanzhafStrathmann, J.; et al. C9orf72 FTLD/ALS-associated Gly-Ala dipeptide repeat proteins cause neuronal toxicity and Unc119 sequestration. Acta Neuropathol. 2014, 128, 485-503. [CrossRef] [PubMed] 
92. Yamakawa, M.; Ito, D.; Honda, T.; Kubo, K.-I.; Noda, M.; Nakajima, K.; Suzuki, N. Characterization of the dipeptide repeat protein in the molecular pathogenesis of c9FTD/ALS. Hum. Mol. Genet. 2015, 24, 1630-1645. [CrossRef] [PubMed]

93. Chang, Y.-J.; Jeng, U.-S.; Chiang, Y.-L.; Hwang, I.-S.; Chen, Y.-R. The Glycine-Alanine Dipeptide Repeat from C9orf72 Hexanucleotide Expansions Forms Toxic Amyloids Possessing Cell-to-Cell Transmission Properties. J. Biol. Chem. 2016, 291, 4903-4911. [CrossRef]

94. Swaminathan, A.; Bouffard, M.; Liao, M.; Ryan, S.; Callister, J.B.; Pickering-Brown, S.M.; Armstrong, G.A.B.; Drapeau, P. Expression of C9orf72-related dipeptides impairs motor function in a vertebrate model. Hum. Mol. Genet. 2018, 27, 1754-1762. [CrossRef]

95. Swinnen, B.; Bento-Abreu, A.; Gendron, T.F.; Boeynaems, S.; Bogaert, E.; Nuyts, R.; Timmers, M.; Scheveneels, W.; Hersmus, N.; Wang, J.; et al. A zebrafish model for C9orf72 ALS reveals RNA toxicity as a pathogenic mechanism. Acta Neuropathol. 2018, 135, 427-443. [CrossRef]

96. Ohki, Y.; Wenninger-Weinzierl, A.; Hruscha, A.; Asakawa, K.; Kawakami, K.; Haass, C.; Edbauer, D.; Schmid, B. Glycine-alanine dipeptide repeat protein contributes to toxicity in a zebrafish model of C9orf72 associated neurodegeneration. Mol. Neurodegener. 2017, 12, 6. [CrossRef]

97. Lee, K.-H.; Zhang, P.; Kim, H.J.; Mitrea, D.M.; Sarkar, M.; Freibaum, B.D.; Cika, J.; Coughlin, M.; Messing, J.; Molliex, A.; et al. C9orf72 Dipeptide Repeats Impair the Assembly, Dynamics, and Function of Membrane-Less Organelles. Cell 2016, 167, 774-788.e17. [CrossRef]

98. Freibaum, B.D.; Lu, Y.; Lopez-Gonzalez, R.; Kim, N.C.; Almeida, S.; Lee, K.-H.; Badders, N.; Valentine, M.; Miller, B.L.; Wong, P.C.; et al. GGGGCC repeat expansion in C9orf72 compromises nucleocytoplasmic transport. Nature 2015, 525, 129-133. [CrossRef]

99. Zhang, Y.-J.; Gendron, T.F.; Grima, J.C.; Sasaguri, H.; Jansen-West, K.; Xu, Y.-F.; Katzman, R.B.; Gass, J.; Murray, M.E.; Shinohara, M.; et al. C9ORF72 poly(GA) aggregates sequester and impair HR23 and nucleocytoplasmic transport proteins. Nat. Neurosci. 2016, 19, 668-677. [CrossRef]

100. Schludi, M.H.; Becker, L.; Garrett, L.; Gendron, T.F.; Zhou, Q.; Schreiber, F.; Popper, B.; Dimou, L.; Strom, T.M.; Winkelmann, J.; et al. Spinal poly-GA inclusions in a C9orf72 mouse model trigger motor deficits and inflammation without neuron loss. Acta Neuropathol. 2017, 134, 241-254. [CrossRef]

101. Yang, D.; Abdallah, A.; Li, Z.; Lu, Y.; Almeida, S.; Gao, F.-B. FTD/ALS-associated poly(GR) protein impairs the Notch pathway and is recruited by poly(GA) into cytoplasmic inclusions. Acta Neuropathol. 2015, 130, 525-535. [CrossRef] [PubMed]

102. Mizielinska, S.; Grönke, S.; Niccoli, T.; Ridler, C.E.; Clayton, E.L.; Devoy, A.; Moens, T.; Norona, F.E.; Woollacott, I.O.C.; Pietrzyk, J.; et al. C9orf72 repeat expansions cause neurodegeneration in Drosophila through arginine-rich proteins. Science 2014, 345, 1192-1194. [CrossRef] [PubMed]

103. Sakae, N.; Bieniek, K.F.; Zhang, Y.-J.; Ross, K.; Gendron, T.F.; Murray, M.E.; Rademakers, R.; Petrucelli, L.; Dickson, D. Poly-GR dipeptide repeat polymers correlate with neurodegeneration and Clinicopathological subtypes in C9ORF72-related brain disease. Acta Neuropathol. Commun. 2018, 6, 63. [CrossRef] [PubMed]

104. Kwon, I.; Xiang, S.; Kato, M.; Wu, L.; Theodoropoulos, P.; Wang, T.; Kim, J.; Yun, J.; Xie, Y.; McKnight, S.L. Poly-dipeptides encoded by the C9orf72 repeats bind nucleoli, impede RNA biogenesis, and kill cells. Science 2014, 345, 1139-1145. [CrossRef]

105. Flores, B.N.; Dulchavsky, M.; Krans, A.; Sawaya, M.R.; Paulson, H.L.; Todd, P.K.; Barmada, S.J.; Ivanova, M.I. Distinct C9orf72Associated Dipeptide Repeat Structures Correlate with Neuronal Toxicity. PLoS ONE 2016, 11, e0165084. [CrossRef]

106. Boeynaems, S.; Bogaert, E.; Kovacs, D.; Konijnenberg, A.; Timmerman, E.; Volkov, A.; Guharoy, M.; De Decker, M.; Jaspers, T.; Ryan, V.H.; et al. Phase Separation of C9orf72 Dipeptide Repeats Perturbs Stress Granule Dynamics. Mol. Cell 2017, 65, 1044-1055.e5. [CrossRef]

107. Zhang, K.; Daigle, J.G.; Cunningham, K.M.; Coyne, A.N.; Ruan, K.; Grima, J.C.; Bowen, K.E.; Wadhwa, H.; Yang, P.; Rigo, F.; et al. Stress Granule Assembly Disrupts Nucleocytoplasmic Transport. Cell 2018, 173, 958-971.e17. [CrossRef]

108. White, M.R.; Mitrea, D.M.; Zhang, P.; Stanley, C.B.; Cassidy, D.E.; Nourse, A.; Phillips, A.H.; Tolbert, M.; Taylor, J.P.; Kriwacki, R.W. C9orf72 Poly(PR) Dipeptide Repeats Disturb Biomolecular Phase Separation and Disrupt Nucleolar Function. Mol. Cell 2019, 74, 713-728.e6. [CrossRef]

109. Shorter, J. Phase separation of RNA-binding proteins in physiology and disease: An introduction to the JBC Reviews thematic series. J. Biol. Chem. 2019, 294, 7113-7114. [CrossRef]

110. Rossi, S.; Serrano, A.; Gerbino, V.; Giorgi, A.; Di Francesco, L.; Nencini, M.; Bozzo, F.; Schininà, M.E.; Bagni, C.; Cestra, G.; et al. Nuclear accumulation of mRNAs underlies G4C2-repeat-induced translational repression in a cellular model of C9orf72 ALS. J. Cell Sci. 2015, 128, 1787-1799. [CrossRef]

111. Moens, T.G.; Niccoli, T.; Wilson, K.M.; Atilano, M.L.; Birsa, N.; Gittings, L.M.; Holbling, B.V.; Dyson, M.C.; Thoeng, A.; Neeves, J.; et al. C9orf72 arginine-rich dipeptide proteins interact with ribosomal proteins in vivo to induce a toxic translational arrest that is rescued by eIF1A. Acta Neuropathol. 2019, 137, 487-500. [CrossRef] [PubMed]

112. Cheng, W.; Wang, S.; Mestre, A.A.; Fu, C.; Makarem, A.; Xian, F.; Hayes, L.R.; Lopez-Gonzalez, R.; Drenner, K.; Jiang, J.; et al. C9ORF72 GGGGCC repeat-associated non-AUG translation is upregulated by stress through eIF2 $\alpha$ phosphorylation. Nat. Commun. 2018, 9, 51. [CrossRef] [PubMed]

113. Hartmann, H.; Hornburg, D.; Czuppa, M.; Bader, J.M.; Michaelsen, M.; Farny, D.; Arzberger, T.; Mann, M.; Meissner, F.; Edbauer, D. Proteomics and C9orf72 neuropathology identify ribosomes as poly-GR/PR interactors driving toxicity. Life Sci. Alliance 2018, 1, e201800070. [CrossRef] [PubMed] 
114. Zhang, Y.-J.; Gendron, T.F.; Ebbert, M.T.W.; O’Raw, A.D.; Yue, M.; Jansen-West, K.; Zhang, X.; Prudencio, M.; Chew, J.; Cook, C.N.; et al. Poly(GR) impairs protein translation and stress granule dynamics in C9orf72-associated frontotemporal dementia and amyotrophic lateral sclerosis. Nat. Med. 2018, 24, 1136-1142. [CrossRef] [PubMed]

115. Lopez-Gonzalez, R.; Lu, Y.; Gendron, T.F.; Karydas, A.; Tran, H.; Yang, D.; Petrucelli, L.; Miller, B.L.; Almeida, S.; Gao, F.-B. Poly(GR) in C9ORF72-Related ALS/FTD Compromises Mitochondrial Function and Increases Oxidative Stress and DNA Damage in iPSC-Derived Motor Neurons. Neuron 2016, 92, 383-391. [CrossRef]

116. Choi, S.Y.; Lopez-Gonzalez, R.; Krishnan, G.; Phillips, H.L.; Li, A.N.; Seeley, W.W.; Yao, W.-D.; Almeida, S.; Gao, F.-B. C9ORF72ALS/FTD-associated poly(GR) binds Atp5a1 and compromises mitochondrial function in vivo. Nat. Neurosci. 2019, 22, 851-862. [CrossRef]

117. Zhang, K.; Donnelly, C.J.; Haeusler, A.R.; Grima, J.C.; Machamer, J.B.; Steinwald, P.; Daley, E.L.; Miller, S.J.; Cunningham, K.M.; Vidensky, S.; et al. The C9orf72 repeat expansion disrupts nucleocytoplasmic transport. Nature 2015, 525, 56-61. [CrossRef]

118. Boeynaems, S.; Bogaert, E.; Michiels, E.; Gijselinck, I.; Sieben, A.; Jovičić, A.; De Baets, G.; Scheveneels, W.; Steyaert, J.; Cuijt, I.; et al. Drosophila screen connects nuclear transport genes to DPR pathology in c9ALS/FTD. Sci. Rep. 2016, 6, 20877. [CrossRef]

119. Khosravi, B.; Hartmann, H.; May, S.; Möhl, C.; Ederle, H.; Michaelsen, M.; Schludi, M.H.; Dormann, D.; Edbauer, D. Cytoplasmic poly-GA aggregates impair nuclear import of TDP-43 in C9orf72 ALS/FTLD. Hum. Mol. Genet. 2017, 26, 790-800. [CrossRef]

120. Yang, Q.; Zhou, J.-W. Neuroinflammation in the central nervous system: Symphony of glial cells. Glia 2019, 67, 1017-1035. [CrossRef]

121. Ghasemi, M.; Fatemi, A. Pathologic role of glial nitric oxide in adult and pediatric neuroinflammatory diseases. Neurosci. Biobehav. Rev. 2014, 45, 168-182. [CrossRef] [PubMed]

122. Block, M.L.; Zecca, L.; Hong, J.-S. Microglia-mediated neurotoxicity: Uncovering the molecular mechanisms. Nat. Rev. Neurosci. 2007, 8, 57-69. [CrossRef] [PubMed]

123. Ginhoux, F.; Greter, M.; Leboeuf, M.; Nandi, S.; See, P.; Gokhan, S.; Mehler, M.F.; Conway, S.J.; Ng, L.G.; Stanley, E.R.; et al. Fate Mapping Analysis Reveals That Adult Microglia Derive from Primitive Macrophages. Science 2010, 330, 841-845. [CrossRef] [PubMed]

124. Aarum, J.; Sandberg, K.; Haeberlein, S.L.B.; Persson, M.A. Migration and differentiation of neural precursor cells can be directed by microglia. Proc. Natl. Acad. Sci. USA 2003, 100, 15983-15988. [CrossRef]

125. Kettenmann, H.; Hanisch, U.-K.; Noda, M.; Verkhratsky, A. Physiology of Microglia. Physiol. Rev. 2011, 91, 461-553. [CrossRef]

126. Morgan, S.C.; Taylor, D.L.; Pocock, J.M. Microglia release activators of neuronal proliferation mediated by activation of mitogenactivated protein kinase, phosphatidylinositol-3-kinase/Akt and delta-Notch signalling cascades. J. Neurochem. 2004, 90, 89-101. [CrossRef]

127. Simard, M.; Nedergaard, M. The neurobiology of glia in the context of water and ion homeostasis. Neuroscience 2004, 129, 877-896. [CrossRef]

128. Li, K.; Li, J.; Zheng, J.; Qin, S. Reactive Astrocytes in Neurodegenerative Diseases. Aging Dis. 2019, 10, 664-675. [CrossRef]

129. Kacerovsky, J.B.; Murai, K.K. Stargazing: Monitoring subcellular dynamics of brain astrocytes. Neuroscience 2016, 323, 84-95. [CrossRef]

130. Volterra, A.; Meldolesi, J. Astrocytes, from brain glue to communication elements: The revolution continues. Nat. Rev. Neurosci. 2005, 6, 626-640. [CrossRef]

131. Liddelow, S.A.; Barres, B.A. Reactive Astrocytes: Production, Function, and Therapeutic Potential. Immunity 2017, 46, 957-967. [CrossRef] [PubMed]

132. Zamanian, J.L.; Xu, L.; Foo, L.C.; Nouri, N.; Zhou, L.; Giffard, R.G.; Barres, B.A. Genomic Analysis of Reactive Astrogliosis. J. Neurosci. 2012, 32, 6391-6410. [CrossRef] [PubMed]

133. Lall, D.; Baloh, R.H. Microglia and C9orf72 in neuroinflammation and ALS and frontotemporal dementia. J. Clin. Investig. 2017, 127, 3250-3258. [CrossRef] [PubMed]

134. Shao, Q.; Yang, M.; Liang, C.; Ma, L.; Zhang, W.; Jiang, Z.; Luo, J.; Lee, J.-K.; Liang, C.; Chen, J.-F. C9orf72 and smcr8 mutant mice reveal MTORC1 activation due to impaired lysosomal degradation and exocytosis. Autophagy 2020, 16, 1635-1650. [CrossRef] [PubMed]

135. Ho, W.Y.; Navakkode, S.; Liu, F.; Soong, T.W.; Ling, S.-C. Deregulated expression of a longevity gene, Klotho, in the C9orf72 deletion mice with impaired synaptic plasticity and adult hippocampal neurogenesis. Acta Neuropathol. Commun. 2020, 8, 155. [CrossRef] [PubMed]

136. Prudencio, M.; Belzil, V.V.; Batra, R.; Ross, C.A.; Gendron, T.F.; Pregent, L.J.; Murray, M.E.; Overstreet, K.K.; Piazza-Johnston, A.E.; Desaro, P.; et al. Distinct brain transcriptome profiles in C9orf72-associated and sporadic ALS. Nat. Neurosci. 2015, 18, 1175-1182. [CrossRef]

137. Umoh, M.E.; Dammer, E.B.; Dai, J.; Duong, D.M.; Lah, J.J.; Levey, A.I.; Gearing, M.; Glass, J.D.; Seyfried, N.T. A proteomic network approach across the ALS-FTD disease spectrum resolves clinical phenotypes and genetic vulnerability in human brain. EMBO Mol. Med. 2018, 10, 48-62. [CrossRef]

138. Oeckl, P.; Weydt, P.; Steinacker, P.; Anderl-Straub, S.; Nordin, F.; Volk, A.E.; Diehl-Schmid, J.; Andersen, P.M.; Kornhuber, J.; Danek, A.; et al. Different neuroinflammatory profile in amyotrophic lateral sclerosis and frontotemporal dementia is linked to the clinical phase. J. Neurol. Neurosurg. Psychiatry 2019, 90, 4-10. [CrossRef] 
139. Liu, Y.; Pattamatta, A.; Zu, T.; Reid, T.; Bardhi, O.; Borchelt, D.R.; Yachnis, A.T.; Ranum, L.P.W. C9orf72 BAC Mouse Model with Motor Deficits and Neurodegenerative Features of ALS/FTD. Neuron 2016, 90, 521-534. [CrossRef]

140. Cistaro, A.; Pagani, M.; Montuschi, A.; Calvo, A.; Moglia, C.; Canosa, A.; Restagno, G.; Brunetti, M.; Traynor, B.J.; Nobili, F.; et al. The metabolic signature of C9ORF72-related ALS: FDG PET comparison with nonmutated patients. Eur. J. Nucl. Med. Mol. Imaging 2014, 41, 844-852. [CrossRef]

141. Brettschneider, J.; Toledo, J.B.; Van Deerlin, V.M.; Elman, L.; McCluskey, L.; Lee, V.M.-Y.; Trojanowski, J.Q. Microglial Activation Correlates with Disease Progression and Upper Motor Neuron Clinical Symptoms in Amyotrophic Lateral Sclerosis. PLoS ONE 2012, 7, e39216. [CrossRef] [PubMed]

142. Cardenas, A.M.; Sarlls, J.E.; Kwan, J.Y.; Bageac, D.; Gala, Z.S.; Danielian, L.E.; Ray-Chaudhury, A.; Wang, H.-W.; Miller, K.L.; Foxley, S.; et al. Pathology of callosal damage in ALS: An ex-vivo, 7 T diffusion tensor MRI study. NeuroImage Clin. 2017, 15, 200-208. [CrossRef] [PubMed]

143. Heller, C.; Foiani, M.S.; Moore, K.M.; Convery, R.S.; Bocchetta, M.; Neason, M.; Cash, D.M.; Thomas, D.L.; Greaves, C.V.; Woollacott, I.O.C.; et al. Plasma glial fibrillary acidic protein is raised in progranulin-associated frontotemporal dementia. $J$. Neurol. Neurosurg. Psychiatry 2020, 91, 263-270. [CrossRef]

144. Chistiakov, D.A.; Killingsworth, M.C.; Myasoedova, V.A.; Orekhov, A.N.; Bobryshev, Y.V. CD68/macrosialin: Not just a histochemical marker. Lab. Investig. 2017, 97, 4-13. [CrossRef]

145. Zotova, E.; Bharambe, V.; Cheaveau, M.; Morgan, W.; Holmes, C.; Harris, S.; Neal, J.W.; Love, S.; Nicoll, J.A.R.; Boche, D. Inflammatory components in human Alzheimer's disease and after active amyloid- $\beta 42$ immunization. Brain 2013, 136, $2677-2696$. [CrossRef] [PubMed]

146. Walker, D.G.; Lue, L.-F. Immune phenotypes of microglia in human neurodegenerative disease: Challenges to detecting microglial polarization in human brains. Alzheimer's Res. Ther. 2015, 7, 56. [CrossRef] [PubMed]

147. Martinez, F.O.; Helming, L.; Milde, R.; Varin, A.; Melgert, B.N.; Draijer, C.; Thomas, B.; Fabbri, M.; Crawshaw, A.; Ho, L.P.; et al. Genetic programs expressed in resting and IL-4 alternatively activated mouse and human macrophages: Similarities and differences. Blood 2013, 121, e57-e69. [CrossRef] [PubMed]

148. Ito, D.; Imai, Y.; Ohsawa, K.; Nakajima, K.; Fukuuchi, Y.; Kohsaka, S. Microglia-specific localisation of a novel calcium binding protein, Iba1. Mol. Brain Res. 1998, 57, 1-9. [CrossRef]

149. Ising, C.; Venegas, C.; Zhang, S.; Scheiblich, H.; Schmidt, S.V.; Vieira-Saecker, A.; Schwartz, S.; Albasset, S.; McManus, R.M.; Tejera, D.; et al. NLRP3 inflammasome activation drives tau pathology. Nature 2019, 575, 669-673. [CrossRef]

150. Dominy, S.S.; Lynch, C.; Ermini, F.; Benedyk, M.; Marczyk, A.; Konradi, A.; Nguyen, M.; Haditsch, U.; Raha, D.; Griffin, C.; et al. Porphyromonas gingivalis in Alzheimer's disease brains: Evidence for disease causation and treatment with small-molecule inhibitors. Sci. Adv. 2019, 5, eaau3333. [CrossRef]

151. Ohsawa, K.; Imai, Y.; Sasaki, Y.; Kohsaka, S. Microglia/macrophage-specific protein Iba1 binds to fimbrin and enhances its actin-bundling activity. J. Neurochem. 2004, 88, 844-856. [CrossRef] [PubMed]

152. Mizielinska, S.; Lashley, T.; Norona, F.E.; Clayton, E.L.; Ridler, C.E.; Fratta, P.; Isaacs, A.M. C9orf72 frontotemporal lobar degeneration is characterised by frequent neuronal sense and antisense RNA foci. Acta Neuropathol. 2013, 126, 845-857. [CrossRef] [PubMed]

153. DeJesus-Hernandez, M.; Finch, N.A.; Wang, X.; Gendron, T.F.; Bieniek, K.F.; Heckman, M.G.; Vasilevich, A.; Murray, M.E.; Rousseau, L.; Weesner, R.; et al. In-depth clinico-pathological examination of RNA foci in a large cohort of C9ORF72 expansion carriers. Acta Neuropathol. 2017, 134, 255-269. [CrossRef] [PubMed]

154. MacKenzie, I.R.; Arzberger, T.; Kremmer, E.; Troost, D.; Lorenzl, S.; Mori, K.; Weng, S.-M.; Haass, C.; Kretzschmar, H.A.; Edbauer, D.; et al. Dipeptide repeat protein pathology in C9ORF72 mutation cases: Clinico-pathological correlations. Acta Neuropathol. 2013, 126, 859-879. [CrossRef] [PubMed]

155. Saberi, S.; Stauffer, J.E.; Jiang, J.; Garcia, S.D.; Taylor, A.E.; Schulte, D.; Ohkubo, T.; Schloffman, C.L.; Maldonado, M.; Baughn, M.; et al. Sense-encoded poly-GR dipeptide repeat proteins correlate to neurodegeneration and uniquely co-localize with TDP-43 in dendrites of repeat-expanded C9orf72 amyotrophic lateral sclerosis. Acta Neuropathol. 2018, 135, 459-474. [CrossRef]

156. Peters, O.M.; Cabrera, G.T.; Tran, H.; Gendron, T.F.; McKeon, J.E.; Metterville, J.; Weiss, A.; Wightman, N.; Salameh, J.; Kim, J.; et al. Human C9ORF72 Hexanucleotide Expansion Reproduces RNA Foci and Dipeptide Repeat Proteins but Not Neurodegeneration in BAC Transgenic Mice. Neuron 2015, 88, 902-909. [CrossRef]

157. Westergard, T.; Jensen, B.K.; Wen, X.; Cai, J.; Kropf, E.; Iacovitti, L.; Pasinelli, P.; Trotti, D. Cell-to-Cell Transmission of Dipeptide Repeat Proteins Linked to C9orf72-ALS/FTD. Cell Rep. 2016, 17, 645-652. [CrossRef]

158. Michell-Robinson, M.A.; Touil, H.; Healy, L.M.; Owen, D.R.; Durafourt, B.A.; Bar-Or, A.; Antel, J.P.; Moore, C.S. Roles of microglia in brain development, tissue maintenance and repair. Brain 2015, 138, 1138-1159. [CrossRef]

159. Verkhratsky, A.; Nedergaard, M. Physiology of Astroglia. Physiol. Rev. 2018, 98, 239-389. [CrossRef]

160. Murray, M.E.; DeJesus-Hernandez, M.; Rutherford, N.J.; Baker, M.; Duara, R.; Graff-Radford, N.R.; Wszolek, Z.K.; Ferman, T.J.; Josephs, K.A.; Boylan, K.B.; et al. Clinical and neuropathologic heterogeneity of c9FTD/ALS associated with hexanucleotide repeat expansion in C9ORF72. Acta Neuropathol. 2011, 122, 673-690. [CrossRef]

161. Brettschneider, J.; Arai, K.; Del Tredici, K.; Toledo, J.B.; Robinson, J.L.; Lee, E.B.; Kuwabara, S.; Shibuya, K.; Irwin, D.J.; Fang, L.; et al. TDP-43 pathology and neuronal loss in amyotrophic lateral sclerosis spinal cord. Acta Neuropathol. 2014, 128, $423-437$. [CrossRef] [PubMed] 
162. Fatima, M.; Tan, R.; Halliday, G.M.; Kril, J.J. Spread of pathology in amyotrophic lateral sclerosis: Assessment of phosphorylated TDP-43 along axonal pathways. Acta Neuropathol. Commun. 2015, 3, 47. [CrossRef] [PubMed]

163. Meyer, K.; Ferraiuolo, L.; Miranda, C.J.; Likhite, S.; McElroy, S.; Renusch, S.; Ditsworth, D.; Lagier-Tourenne, C.; Smith, R.A.; Ravits, J.; et al. Direct conversion of patient fibroblasts demonstrates non-cell autonomous toxicity of astrocytes to motor neurons in familial and sporadic ALS. Proc. Natl. Acad. Sci. USA 2014, 111, 829-832. [CrossRef] [PubMed]

164. Madill, M.; McDonagh, K.; Ma, J.; Vajda, A.; McLoughlin, P.; O’Brien, T.; Hardiman, O.; Shen, S. Amyotrophic lateral sclerosis patient iPSC-derived astrocytes impair autophagy via non-cell autonomous mechanisms. Mol. Brain 2017, 10, 22. [CrossRef] [PubMed]

165. Varcianna, A.; Myszczynska, M.A.; Castelli, L.M.; O’Neill, B.; Kim, Y.; Talbot, J.; Nyberg, S.; Nyamali, I.; Heath, P.R.; Stopford, M.J.; et al. Micro-RNAs secreted through astrocyte-derived extracellular vesicles cause neuronal network degeneration in C9orf72 ALS. EBioMedicine 2019, 40, 626-635. [CrossRef] [PubMed]

166. Allen, S.P.; Hall, B.; Castelli, L.M.; Francis, L.; Woof, R.; Siskos, A.P.; Kouloura, E.; Gray, E.; Thompson, A.G.; Talbot, K.; et al. Astrocyte adenosine deaminase loss increases motor neuron toxicity in amyotrophic lateral sclerosis. Brain 2019, 142, $586-605$. [CrossRef]

167. Allen, S.P.; Hall, B.; Woof, R.; Francis, L.; Gatto, N.; Shaw, A.C.; Myszczynska, M.; Hemingway, J.; Coldicott, I.; Willcock, A.; et al. C9orf72 expansion within astrocytes reduces metabolic flexibility in amyotrophic lateral sclerosis. Brain 2019, 142, 3771-3790. [CrossRef]

168. Onesto, E.; Colombrita, C.; Gumina, V.; Borghi, M.O.; Dusi, S.; Doretti, A.; Fagiolari, G.; Invernizzi, F.; Moggio, M.; Tiranti, V.; et al. Gene-specific mitochondria dysfunctions in human TARDBP and C9ORF72 fibroblasts. Acta Neuropathol. Commun. $2016,4,47$. [CrossRef]

169. Fomin, V.; Richard, P.; Hoque, M.; Li, C.; Gu, Z.; Fissore-O'Leary, M.; Tian, B.; Prives, C.; Manley, J.L. The C9ORF72 Gene, Implicated in Amyotrophic Lateral Sclerosis and Frontotemporal Dementia, Encodes a Protein That Functions in Control of Endothelin and Glutamate Signaling. Mol. Cell. Biol. 2018, 38, e00155-18. [CrossRef]

170. D'Antoni, S.; Ranno, E.; Spatuzza, M.; Cavallaro, S.; Catania, M.V. Endothelin-1 Induces Degeneration of Cultured Motor Neurons through a Mechanism Mediated by Nitric Oxide and PI3K/Akt Pathway. Neurotox. Res. 2017, 32, 58-70. [CrossRef]

171. Rostalski, H.; Leskelä, S.; Huber, N.; Katisko, K.; Cajanus, A.; Solje, E.; Marttinen, M.; Natunen, T.; Remes, A.M.; Hiltunen, M.; et al. Astrocytes and Microglia as Potential Contributors to the Pathogenesis of C9orf72 Repeat Expansion-Associated FTLD and ALS. Front. Neurosci. 2019, 13, 486. [CrossRef] [PubMed]

172. Siddique, N.; Siddique, T. Amyotrophic Lateral Sclerosis Overview. In GeneReviews ${ }^{\circledR}$; Adam, M.P., Ardinger, H.H., Pagon, R.A., Wallace, S.E., Bean, L.J.H., Stephens, K., Amemiya, A., Eds.; University of Washington: Seattle, WA, USA, 1993.

173. Goutman, S.A.; Chen, K.S.; Paez-Colasante, X.; Feldman, E.L. Emerging understanding of the genotype-phenotype relationship in amyotrophic lateral sclerosis. Handb. Clin.Neurol. 2018, 148, 603-623. [CrossRef] [PubMed]

174. Gendron, T.F.; Van Blitterswijk, M.; Bieniek, K.F.; Daughrity, L.M.; Jiang, J.; Rush, B.K.; Pedraza, O.; Lucas, J.A.; Murray, M.E.; Desaro, P.; et al. Cerebellar c9RAN proteins associate with clinical and neuropathological characteristics of C9ORF72 repeat expansion carriers. Acta Neuropathol. 2015, 130, 559-573. [CrossRef] [PubMed]

175. Schludi, M.H.; May, S.; Grässer, F.A.; Rentzsch, K.; Kremmer, E.; Küpper, C.; Klopstock, T.; German Consortium for Frontotemporal Lobar Degeneration; Bavarian Brain Banking Alliance; Arzberger, T.; et al. Distribution of dipeptide repeat proteins in cellular models and C9orf72 mutation cases suggests link to transcriptional silencing. Acta Neuropathol. 2015, 130, 537-555. [CrossRef] [PubMed]

176. Gendron, T.F.; Chew, J.; Stankowski, J.N.; Hayes, L.R.; Zhang, Y.-J.; Prudencio, M.; Carlomagno, Y.; Daughrity, L.M.; Jansen-West, K.; Perkerson, E.A.; et al. Poly(GP) proteins are a useful pharmacodynamic marker forC9ORF72-associated amyotrophic lateral sclerosis. Sci. Transl. Med. 2017, 9, eaai7866. [CrossRef] [PubMed]

177. Cardani, R.; Mancinelli, E.; Giagnacovo, M.; Sansone, V.; Meola, G. Ribonuclear inclusions as biomarker of myotonic dystrophy type 2, even in improperly frozen or defrozen skeletal muscle biopsies. Eur. J. Histochem. 2009, 53, 107-111. [CrossRef] [PubMed]

178. Ransohoff, R.M. How neuroinflammation contributes to neurodegeneration. Science 2016, 353, 777-783. [CrossRef] [PubMed]

179. Collins, M.A.; An, J.; Hood, B.L.; Conrads, T.P.; Bowser, R.P. Label-Free LC-MS/MS Proteomic Analysis of Cerebrospinal Fluid Identifies Protein/Pathway Alterations and Candidate Biomarkers for Amyotrophic Lateral Sclerosis. J. Proteome Res. 2015, 14, 4486-4501. [CrossRef] [PubMed]

180. Chen, Y.; Liu, X.-H.; Wu, J.-J.; Ren, H.-M.; Wang, J.; Ding, Z.-T.; Jiang, Y.-P. Proteomic analysis of cerebrospinal fluid in amyotrophic lateral sclerosis. Exp. Ther. Med. 2016, 11, 2095-2106. [CrossRef] [PubMed]

181. Chen, X.; Chen, Y.; Wei, Q.-Q.; Ou, R.; Cao, B.; Zhao, B.; Shang, H. Assessment of a multiple biomarker panel for diagnosis of amyotrophic lateral sclerosis. BMC Neurol. 2016, 16, 173. [CrossRef] [PubMed]

182. Moreau, C.; Gosset, P.; Brunaud-Danel, V.; Lassalle, P.; Degonne, B.; Destée, A.; Defebvre, L.; Devos, D. CSF profiles of angiogenic and inflammatory factors depend on the respiratory status of ALS patients. Amyotroph. Lateral Scler. 2009, 10, 175-181. [CrossRef] [PubMed]

183. Vu, L.T.; Bowser, R.P. Fluid-Based Biomarkers for Amyotrophic Lateral Sclerosis. Neurotherapeutics 2017, 14, 119-134. [CrossRef] [PubMed] 
184. Ismail, A.; Cooper-Knock, J.; Highley, J.R.; Milano, A.; Kirby, J.; Goodall, E.; Lowe, J.; Scott, I.; Constantinescu, C.S.; Walters, S.J.; et al. Concurrence of multiple sclerosis and amyotrophic lateral sclerosis in patients with hexanucleotide repeat expansions of C9ORF72. J. Neurol. Neurosurg. Psychiatry 2013, 84, 79-87. [CrossRef] [PubMed]

185. Katisko, K.; Solje, E.; Korhonen, P.; Jääskeläinen, O.; Loppi, S.; Hartikainen, P.; Koivisto, A.M.; Kontkanen, A.; Korhonen, V.E.; Helisalmi, S.; et al. Peripheral inflammatory markers and clinical correlations in patients with frontotemporal lobar degeneration with and without the C9orf72 repeat expansion. J. Neurol. 2020, 267, 76-86. [CrossRef] [PubMed]

186. Bennett, S.A.; Tanaz, R.; Cobos, S.N.; Torrente, M.P. Epigenetics in amyotrophic lateral sclerosis: A role for histone posttranslational modifications in neurodegenerative disease. Transl. Res. 2019, 204, 19-30. [CrossRef] [PubMed]

187. Benigni, M.; Ricci, C.; Jones, A.R.; Giannini, F.; Al-Chalabi, A.; Battistini, S. Identification of miRNAs as Potential Biomarkers in Cerebrospinal Fluid from Amyotrophic Lateral Sclerosis Patients. NeuroMolecular Med. 2016, 18, 551-560. [CrossRef]

188. De Felice, B.; Annunziata, A.; Fiorentino, G.; Borra, M.; Biffali, E.; Coppola, C.; Cotrufo, R.; Brettschneider, J.; Giordana, M.L.; Dalmay, T.; et al. miR-338-3p is over-expressed in blood, CFS, serum and spinal cord from sporadic amyotrophic lateral sclerosis patients. Neurogenetics 2014, 15, 243-253. [CrossRef]

189. Takahashi, I.; Hama, Y.; Matsushima, M.; Hirotani, M.; Kano, T.; Hohzen, H.; Yabe, I.; Utsumi, J.; Sasaki, H. Identification of plasma microRNAs as a biomarker of sporadic Amyotrophic Lateral Sclerosis. Mol. Brain 2015, 8, 67. [CrossRef]

190. Freischmidt, A.; Müller, K.; Ludolph, A.; Weishaupt, J. Systemic dysregulation of TDP-43 binding microRNAs in amyotrophic lateral sclerosis. Acta Neuropathol. Commun. 2013, 1, 42. [CrossRef]

191. Williams, A.H.; Valdez, G.; Moresi, V.; Qi, X.; McAnally, J.; Elliott, J.L.; Bassel-Duby, R.; Sanes, J.R.; Olson, E.N. MicroRNA-206 Delays ALS Progression and Promotes Regeneration of Neuromuscular Synapses in Mice. Science 2009, 326, 1549-1554. [CrossRef]

192. Bowser, R.; Turner, M.R.; Shefner, J.M. Biomarkers in amyotrophic lateral sclerosis: Opportunities and limitations. Nat. Rev. Neurol. 2011, 7, 631-638. [CrossRef]

193. Mendez, E.F.; Sattler, R. Biomarker development for C9orf72 repeat expansion in ALS. Brain Res. 2015, 1607, 26-35. [CrossRef] [PubMed]

194. De Godoy Rousseff Prado, L.; Bicalho, I.C.S.; Magalhães, D.; Caramelli, P.; Teixeira, A.L.; De Souza, L.C. C9ORF72 and the FTD-ALS spectrum: A systematic review of neuroimaging studies. Dement. Neuropsychol. 2015, 9, 413-421. [CrossRef] [PubMed]

195. Boeve, B.F.; Boylan, K.B.; Graff-Radford, N.R.; DeJesus-Hernandez, M.; Knopman, D.S.; Pedraza, O.; Vemuri, P.; Jones, D.; Lowe, V.; Murray, M.E.; et al. Characterization of frontotemporal dementia and/or amyotrophic lateral sclerosis associated with the GGGGCC repeat expansion in C9ORF72. Brain 2012, 135, 765-783. [CrossRef] [PubMed]

196. Mahoney, C.J.; Beck, J.; Rohrer, J.D.; Lashley, T.; Mok, K.; Shakespeare, T.; Yeatman, T.; Warrington, E.K.; Schott, J.M.; Fox, N.C.; et al. Frontotemporal dementia with the C9ORF72 hexanucleotide repeat expansion: Clinical, neuroanatomical and neuropathological features. Brain 2012, 135, 736-750. [CrossRef] [PubMed]

197. Bede, P.; Bokde, A.L.; Byrne, S.; Elamin, M.; McLaughlin, R.L.; Kenna, K.; Fagan, A.J.; Pender, N.; Bradley, D.G.; Hardiman, O. Multiparametric MRI study of ALS stratified for the C9orf72 genotype. Neurology 2013, 81, 361-369. [CrossRef] [PubMed]

198. Chew, S.; Atassi, N. Positron Emission Tomography Molecular Imaging Biomarkers for Amyotrophic Lateral Sclerosis. Front. Neurol. 2019, 10, 135. [CrossRef]

199. Zürcher, N.R.; Loggia, M.L.; Lawson, R.; Chonde, D.B.; Izquierdo-Garcia, D.; Yasek, J.E.; Akeju, O.; Catana, C.; Rosen, B.R.; Cudkowicz, M.E.; et al. Increased in vivo glial activation in patients with amyotrophic lateral sclerosis: Assessed with [ $\left.{ }^{11} \mathrm{C}\right]-\mathrm{PBR} 28$. NeuroImage Clin. 2015, 7, 409-414. [CrossRef]

200. Alshikho, M.J.; Zürcher, N.R.; Loggia, M.; Cernasov, P.; Reynolds, B.; Pijanowski, O.; Chonde, D.B.; Izquierdo-Garcia, D.; Mainero, C.; Catana, C.; et al. Integrated magnetic resonance imaging and $\left[{ }^{11} \mathrm{C}\right]-\mathrm{PBR} 28$ positron emission tomographic imaging in amyotrophic lateral sclerosis. Ann. Neurol. 2018, 83, 1186-1197. [CrossRef]

201. Alshikho, M.J.; Zürcher, N.R.; Loggia, M.L.; Cernasov, P.; Chonde, D.B.; Izquierdo-Garcia, D.; Yasek, J.E.; Akeju, O.; Catana, C.; Rosen, B.R.; et al. Glial activation colocalizes with structural abnormalities in amyotrophic lateral sclerosis. Neurology 2016, 87, 2554-2561. [CrossRef]

202. Dolgin, E. The brain's traffic problems. Science 2019, 363, 221-223. [CrossRef] [PubMed] 